\title{
Chemically Modified Biosorbents and Their Role in the Removal of Emerging Pharmaceutical Waste in the Water System
}

\author{
Adewale Adewuyi \\ Department of Chemical Sciences, Faculty of Natural Sciences, Redeemer's University, P.M.B 230, Ede, \\ Osun State, Nigeria; walexy62@yahoo.com; Tel.: +234-8035826679
}

Received: 29 April 2020; Accepted: 26 May 2020; Published: 29 May 2020

\begin{abstract}
Presence of pharmaceutically active compounds (PACs) as emerging contaminants in water is a major concern. Recent reports have confirmed the presence of PACs in natural and wastewater systems, which have caused several problems indicating the urgent need for their removal. The current review evaluates the role of chemically modified biosorbents in the removal of PACs in water. Reported biosorbents include plant and animal solid waste, microorganisms and bio-composite. Bio-composites exhibited better prospects when compared with other biosorbents. Types of chemical treatment reported include acid, alkaline, solvent extraction, metal salt impregnation and surface grafting, with alkaline treatment exhibiting better results when compared with other treatments. The biosorption processes mostly obeyed the pseudo-second-order model and the Langmuir isotherm model in a process described mainly by ionic interaction. Desorption and regeneration capacity are very important in selecting an appropriate biosorbent for the biosorption process. Depending on the type of biosorbent, the cost of water treatment per million liters of water was estimated as US $\$ 10-$ US $\$ 200$, which presents biosorption as a cheap process compared to other known water treatment processes. However, there is a need to conduct large-scale studies on the biosorption process for removing PACs in water.
\end{abstract}

Keywords: algae; bacteria; biosorbent; biosorption; pharmaceutical waste

\section{Introduction}

Lack of sufficient clean drinking water is a growing challenge in many countries. Most surface and groundwater bodies are contaminated and are not directly safe for consumption without being treated. Surface and ground waters in rural communities that were once clean are now contaminated due to industrialization and abuse in the use and disposal of pharmaceutically active compounds (PACs). Contamination has severely affected the quality of freshwater. This undesired effect harms humans, animals and the ecosystem. Although several measures, such as creating awareness of water quality problems, promoting advanced water cleaning techniques and establishing preventive systems, have been put in place in some countries, the challenge is still persistent with different levels of impact in different countries. Several organic compounds have been reported in water systems; however, the presence of PACs continues to pose a severe problem among these organic compounds. Most PACs are considered as emerging contaminants, since their regulation and limit in domestic and industrial wastewater handling and treatment criteria, in most countries of the world, are not yet specified, most notably in developing countries [1]. They occur in small amounts and are capable of bioaccumulating over a period to cause harm. The danger ascribed to PACs necessitates the development of an environmentally friendly and cost-effective means for their removal in water systems. The consumption of pharmaceutical compounds has increased over the past decade across the 
world. Their use includes application in disease control and eradication in both human and animals. One major problem of this is the uncontrolled use of antimicrobial agents in veterinary medicine as well as the use of over-the-counter drugs in self-medication [2,3]. The abuse of PACs has led to their presence in the environment. They enter the environment when they are excreted from the body system and sometimes when inappropriately disposed of or applied. Having entered the environment, they are capable of transforming into metabolites under certain environmental conditions, temperature, pressure, light, etc., in a process, which can be described as biodegradation and photodegradation. The metabolites are sometimes more toxic than the parent PACs. This transformation makes it difficult to monitor the presence of PACs in their parent forms in surface and groundwater. The presence of PACs and possibly their metabolites have made pathogenic organisms develop resistance against them and, over time, they lose their potency against these disease-causing microorganisms. These emerging contaminants have gained attention as previous researchers have reported toxic and adverse effect even at low concentration [4]. Apart from the development of drug resistance by pathogenic microorganisms, previous studies have linked feminization of fish species to the presence of natural and synthetic estrogens in water [5-7].

PACs are a wide range of chemical compounds, which may include anti-inflammatories, antibiotics, cytotoxins, birth control pills, synthetic hormones, and statins. They are different from other chemical contaminants found in water because innumerable complex molecules may form them; the molecules are absorbed in the human body and may undergo metabolic reactions that can modify their chemical structure; they may persist in the environment and may be amphiphilic [8]. Several PACs have been detected in surface water, which varies from region to region, as shown in Table 1. Many sources may have contributed to their presence in surface water; primary sources are urban, industrial, domestic and hospital wastewater. Intensive livestock farming, liquid livestock manure, sewage sludge from agricultural practice and effluents from sewage treatment plants may also serve as sources.

Table 1. Pharmaceutically active compounds (PACs) reported in surface water.

\begin{tabular}{|c|c|c|c|}
\hline PACs & Country & Concentration $\left(\mathrm{ng} \mathrm{L}^{-1}\right)$ * & Reference \\
\hline \multicolumn{4}{|l|}{ Antibiotics } \\
\hline Erythromycin & Bangladesh & 6.46 & [9] \\
\hline Metronidazole & China & 5.10 & [10] \\
\hline Sulfamethoxazole & USA & 14.73 & [11] \\
\hline Trimethoprim & Mexico & 74.00 & [12] \\
\hline Ciprofloxacin & India & $6,500,000$ & [13] \\
\hline Amoxicillin & Ghana & 2.70 & [14] \\
\hline Trimethoprim & Kenya & 2650 & [15] \\
\hline Tetracyclin & Ghana & 30.00 & [14] \\
\hline \multicolumn{4}{|l|}{ Anti-hyperglycemic } \\
\hline Metformin & Sweden & 8.40 & [16] \\
\hline \multicolumn{4}{|l|}{ Lipid regulator } \\
\hline Gemfibrozil & Spain & 3735.00 & [17] \\
\hline \multirow{2}{*}{\multicolumn{4}{|c|}{$\begin{array}{c}\text { Analgesics and } \\
\text { Anti-inflammatories }\end{array}$}} \\
\hline & & & \\
\hline Acetaminophen & UK & 9822.00 & [18] \\
\hline Diclofenac & Malaysia & 15.49 & [19] \\
\hline Ibuprofen & South-Africa & 846.00 & [20] \\
\hline Ketoprofen & Portugal & 86.90 & {$[21]$} \\
\hline Naproxen & Poland & 13.40 & [22] \\
\hline \multicolumn{4}{|l|}{ Anti-depressives } \\
\hline Diazepam & India & 305.00 & [23] \\
\hline Fluoxetine & Portugal & 25.37 & [21] \\
\hline
\end{tabular}

* = Maximum concentration reported. 
The different pathways for the introduction of PACs into the environment can be described as reported by Silva et al. [24] in Figure 1. Apart from their presence in surface water, they have percolated into groundwater, and their presence has also been documented in coastal seawater [25]. The consequences of the presence of PACs in water goes beyond the reduction in water quality to environmental persistence and detrimental effect on aquatic life [26].

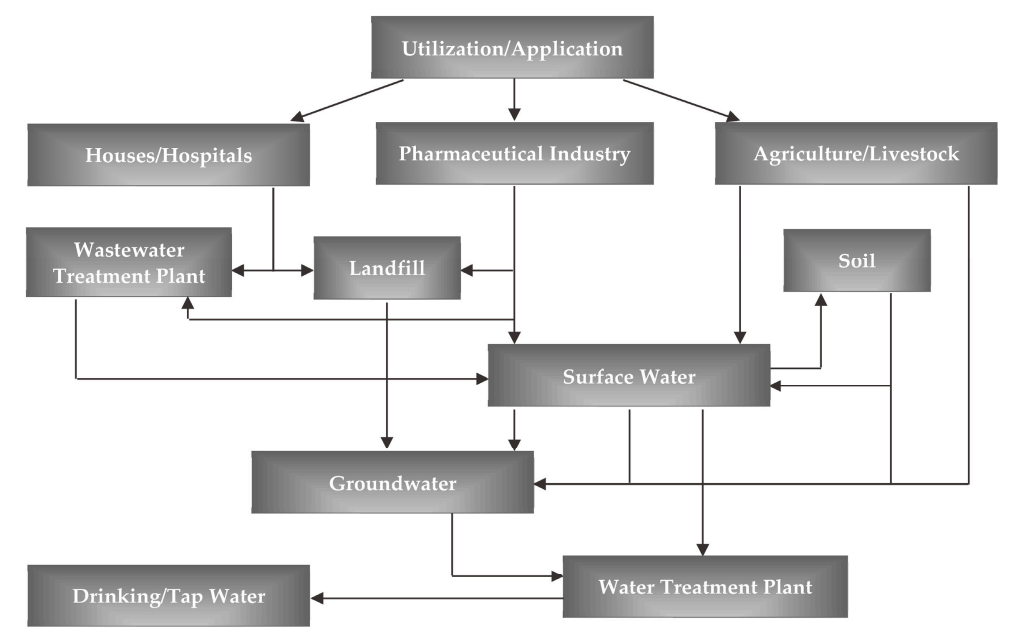

Figure 1. Pathways of PACs' introduction into the environment [24].

There is a need to develop procedures and technology for the complete removal of PACs in water or in wastewater before they are discharged into the environment. Previous techniques used for the removal of PACs from water include chemical, physical and biological approaches, e.g., coagulation, membrane filtration, bioremediation, volatilization, ozonation, flocculation, advance oxidation, photocatalysis, sedimentation, microbial degradation, electrochemical processes and adsorption [27-34]. These approaches differ in effectiveness, sustainability and cost and have different advantages and disadvantages. Unfortunately, sedimentation, coagulation and flocculation processes are not so suitable and effective for the removal of PACs due to the high solubility and mobility of some PACs in water [35]. However, separation processes such as ultra-, nano- and micro-filtrations have been suggested, but their efficiency is mainly dependent on the molecular weight and size of the PACs. Other studies have also shown that the filtration processes might further depend on ionic interaction, membrane functional groups, hydrophobic interaction and age of the membrane [36-38]. Use of advanced electrochemical oxidation has been shown to have the limitation of producing more toxic and recalcitrant by-products than the parent PACs $[39,40]$. Although ozonation processes have been useful, the toxicity of the intermediate compounds formed during the process is not well understood. It becomes necessary to develop an additional unit operation to remove the intermediate molecules formed, which increases production cost and the need for expertise. The biological process has been useful, but the main challenges are incomplete degradation of PACs and production of intermediate compounds, which either need another procedure to remove them or whose toxicity is not well known.

Several steps have been taken to upgrade these techniques, e.g., attempts at combined advanced oxidation processes, ultrasonic irradiation, electrochemical degradation, photodegradation, adsorption, photo-Fenton, etc. [41-44]; however, the upgrade results from the sophistication of these processes. The biosorption process remains relevant because of its process characteristics such as ease of maintenance, simplicity, ease of modification of biosorbents, inexpensive cost, efficiency of uptake even when the adsorbates (PACs) are in low concentrations, lower selectivity and consistency [26,45]. The outstanding performance of biosorption gives it an edge over the other known processes, most notably the ease of modification, which simplifies the process design. For this reason, this review aims to consider the role of chemically modified biosorbents in the removal of PACs from the water system. 


\section{Biosorption as a Process for Removing PACs in Water}

Biosorption is a mass transfer process that moves substances from the fluid phase to the solid phase. It is a physicochemical and metabolically independent process with mechanisms such as ion exchange, precipitation, absorption, adsorption and surface complexation [46]. It has found application in water treatment and, in this case, removal of PACs from the water system. During this process, substances (adsorbate) in the fluid phase interact with the solid phase and are transferred from the fluid to the solid phase (biosorbent). PACs are the adsorbate in the fluid phase while a suitable material capable of interacting with PACs is the solid phase (biosorbent). The process may be conducted in batch (stirred systems) or continuous mode system (fixed-bed column). The process entails three stages: (I) transport of adsorbate in the fluid phase to the surface of the biosorbent, known as film diffusion, (II) movement of the adsorbate to the pores of the biosorbent, or intraparticle diffusion and (III) fixing of the adsorbate on the surface of the biosorbent, surface bonding. The rate-determining step is at stage I or II, while the III stage is usually very fast [8,47]. Biosorption has been used to remove a wide range of contaminants in water, which has included PACs $[29,47,48]$. One significant advantage over other processes is that it does not lead to the formation of intermediates $[26,27]$. The process is reversible, and the adsorbent used can be regenerated by desorption for reuse. However, biosorption may be influenced by certain factors, including $\mathrm{pH}$, temperature, particle size and surface area of the biosorbent. Apart from the surface being large, the surface chemistry must also be appropriate, and the pore size distribution towards PACs must also be correct. Biosorption has received high interest because of the wide range of materials that could be used as biosorbent [49]. The biosorbent used will depend on solubility in water, surface functionality, molecular size and distribution, although it is difficult to predict the performance of any biosorbent at a glance $[24,50]$. The economic viability of the biosorption process will depend on the adsorbate, biosorbent and the process variable employed, although the biosorbent plays a significant role in this regard. Economic feasibility will depend on the biosorption capacity, regeneration and possible modification of the biosorbent $[27,50]$.

The development of cheap and efficient biosorbent is critical as many of the conventional ones lack satisfactory performance [51], which is the reason for introducing processes such as chemical modification to enhance their performance. Although some materials have been used as adsorbents for the purification of wastewater in the past despite their high purification capacities, the challenge is that a few of them are not biodegradable, which gives natural adsorbents priority over synthetic. Over time, several biosorbents have been modified to improve their capacity for the removal of PACs in the water system. Attention has been placed on biosorbents for water treatment because they are from a natural source, are biodegradable, easy to modify, and most are from renewable sources. Attempts have been made also to make use of waste materials as feedstock for the production of biosorbents. This way, waste from wood, agricultural and food industries are converted to useful and cheap low-cost biosorbents, which has emerged as a cost-effective and efficient alternative for water and wastewater treatment.

\subsection{Biosorbents}

Biosorbents are biological materials used to remove pollutants passively from a solution. They include biomaterials like agricultural wastes, algae, bacterial, and industrial wastes. They have been receiving encouraging attention because they are from renewable sources, cheap, biodegradable and, after complete usage, do not generate secondary contaminants [52]. Being biological, they contain lots of functional groups, which is the driving force of the hydrophobic interaction they exhibit during the sorption process, which is mostly $\mathrm{pH}$-dependent [53,54]. Many natural materials have been suggested as promising biosorbents for the removal of pollutants in water. These materials can be inactive or dead microbial biomass, as well as living microorganisms. The mechanism by which this is achieved is fully understood for some biosorbents, whereas some require more detailed study. However, the toxicity of some of these biomaterials remains a subject of discussion, which also requires a detailed study. 
Biomaterials of various sorption capacities are known. The use of these materials depends on not only their sorption capacity but also reusability over time, which forms the basis for selecting them as biosorbents. One of the major challenges is the selection of the best performing type of biosorbent from a large pool of promising and cheap biomaterials. Although most lignocellulosic materials have a small surface area, effort is focused on how to improve their activity as biosorbents. This does not only include sorption capacity but also improvement in regeneration. Comparison of sorption capacity or efficiency of modified and unmodified biosorbents is essential. The modification might be in the form of pretreatment because the use of untreated biosorbents, most especially plant waste materials, can cause the release of organic compounds into the water being treated. Untreated biosorbents may create high chemical oxygen demand, biological oxygen demand and total organic carbon [55], which leads to depletion of water oxygen content. Therefore, modification of the biosorbent is expected to be encompassing; this cleans the biomaterial by preventing the introduction of unwanted organic compounds into the treated water as well as enhancing the ability of the biomaterial to remove PACs. Different types of chemical modification reported for biosorbents are compared in Table 2.

Table 2. Types of chemical modifications and targeted PACs.

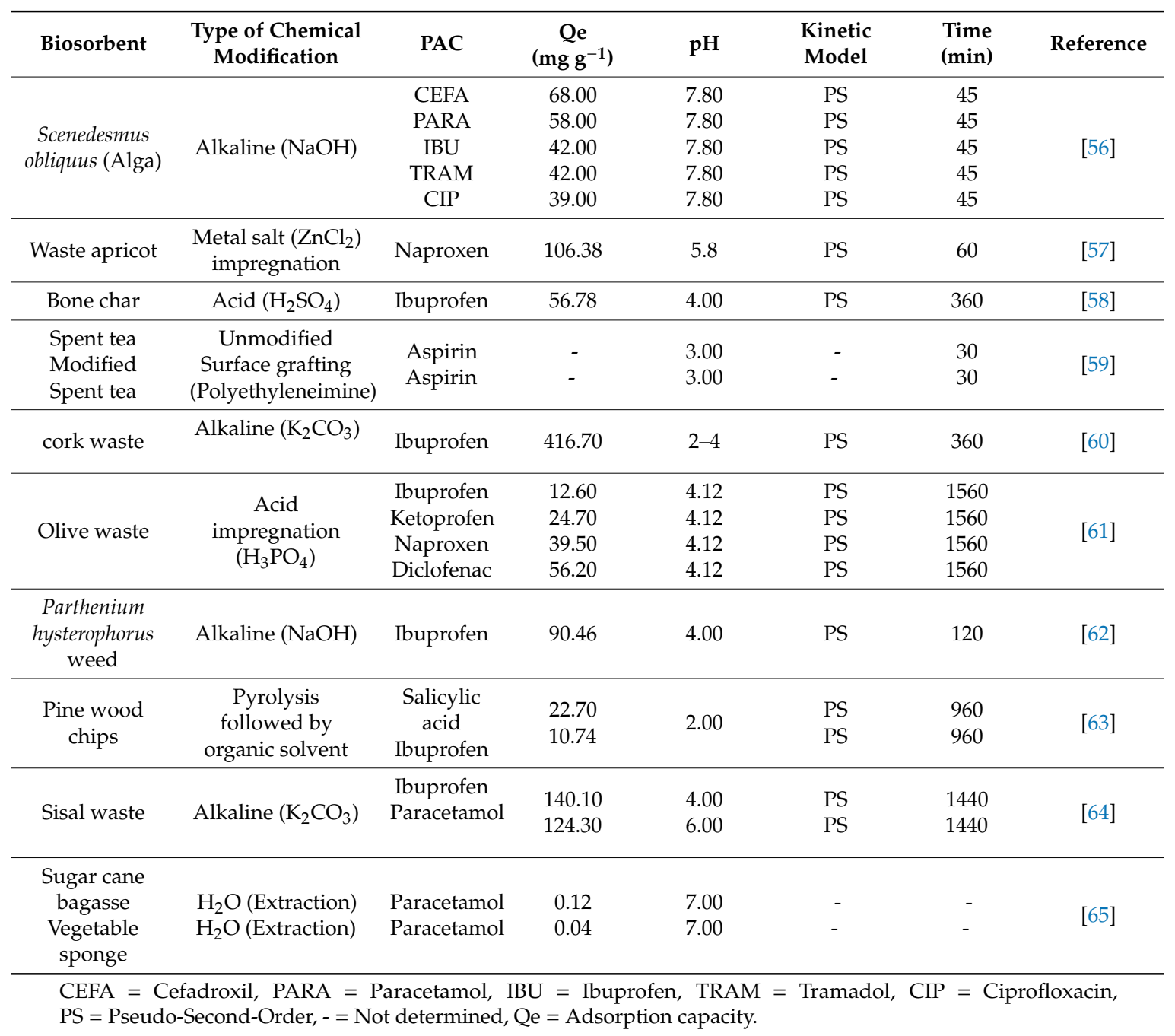

As shown in Table 2, the use of organic solvent after pyrolysis of pine wood chips removed substances that may have leached from the biosorbent into treated water [63]. Similarly, use of water $\left(\mathrm{H}_{2} \mathrm{O}\right)$ in the pretreatment of sugar cane bagasse and vegetable sponge before the treatment of water contaminated with paracetamol also removed substances that might have interfered with the use of 
the biosorbents [65]. Use of alkaline in chemical modification of biosorbents showed better adsorption capacity when compared with other methods. The authors argued that the use of alkaline opens up pores in the biosorbents, which are capable of interacting and trapping the targeted PACs. The kinetic model described the biosorption process for the modified biosorbents as reaching equilibrium in less than $60 \mathrm{~min}$. However, most of the authors allowed the process to keep running for over $60 \mathrm{~min}$ to ascertain the consistency of the equilibria process. Moreover, all the sorption processes obeyed pseudo-second-order kinetics at a $\mathrm{pH}$ in the range 2-7.8. Most authors claimed that biosorption of PACs is favored at acidic or neutral $\mathrm{pH}$. Unmodified and modified spent teas were evaluated for the removal of aspirin from the water system [58]. The study confirmed that the use of polyethyleneimine surface grafted spent tea performed better at a $65 \%$ aspirin removal than unmodified spent tea, which achieved just $1 \%$ removal of aspirin. This further shows that chemical modification has the capacity to improve the performance of biosorbents. Many biosorbents are known for the removal of PACs in water. Based on their numerous forms, they may be classified into four categories: natural, industrial wastes, agricultural wastes and forest wastes $[66,67]$.

\subsection{Plant and Animal Solid Waste Biosorbent}

Plant and animal solid wastes are readily available, cheap and renewable resource materials. They are produced in large amount yearly and usually disposal is a problem. Finding meaningful use of these materials is an important area of research. Making use of these waste materials can help reduce waste load as well as produce economically valuable products $[68,69]$. The plant-sourced wastes are composed mainly of cellulose with the presence of lignin, proteins, hemicellulose, sugars, lipids and starch, which serve as structural components [70]. Studies have shown the capacity of waste materials to remove PACs from water; the different types of waste reported as biosorbents by the authors of these studies for the removal of PACs in water are presented in Table 3.

The table reveals the importance of $\mathrm{pH}$ in the biosorption process. The $\mathrm{pH}$ of the solution plays an important role in the sorption process. The $\mathrm{pH}$ was related to the $\mathrm{pH}_{\mathrm{pzc}}$ (point of zero charges) of the studied biosorbents. The $\mathrm{pH}_{\mathrm{pzc}}$ helps in determining surface properties of the biosorbents. If the $\mathrm{pH}$ of the solution is above $\mathrm{pH}_{\mathrm{pzc}}$, then the functional groups on the surface of the biosorbents may be protonated by excess $\mathrm{H}^{+}$ions whereas if the solution $\mathrm{pH}$ is lower than the $\mathrm{pHpzc}$, the surface of the biosorbents may become deprotonated by excess $\mathrm{OH}^{-}$ions in solution [73]. It was obvious that very high $\mathrm{pH}$ did not work well for most PACs; however, most works in the literature reported $\mathrm{pH}$ around 5-7. This goes a long way in helping to explain the mechanism of action of the biosorbents towards PACs. Most of the reported mechanisms involved electronic interactions between the surface of the biosorbents and PACs. The concentration of the PACs studied in Table 3 varies. Chen et al. [71] reported a concentration range of $5-20 \mathrm{mg} \mathrm{L}^{-1}$ for tetracycline while Wang et al. [75] reported a range of $0.5-32 \mathrm{mg} \mathrm{L}^{-1}$, and a range of $0-100 \mathrm{mg} \mathrm{dm}^{-3}$ for diclofenac [72], and Pouretedal et al. [73], for some PACs, reported a range of $20-200 \mathrm{mg} \mathrm{L}^{-1}$. The concentration range studied has an influence on the biosorption capacity exhibited by the biosorbents. The studies further show that biosorption capacity exhibited increases with increase in concentration. However, most PACs are not expected to be present in the environment at very high concentrations; they are expected to occur in the $\mathrm{ng} \mathrm{L}^{-1}$ but, surprisingly, most authors conducted their studies in ranges $\left(\mathrm{mg} \mathrm{L}^{-1}\right)$, which are higher than reported concentrations of most PACs in surface water as shown in Table 1. The concentration range in the studies may have contributed to the high capacity exhibited by the studied biosorbents. In fact, a range as high as $300 \mathrm{mg} \mathrm{L}^{-1}$ was reported in the study of chemically prepared carbon from date palm leaflets towards the sorption of ciprofloxacin, which was higher than the amount expected in an environmental sample. However, attention must be focused on the use of low concentration range to understand further the exact behavior of chemically modified biosorbents at low concentrations, which reflects the precise concentration of these PACs in the environment. PAC solutions used in most studies are synthetic in nature and studies on sorption efficiency of biosorbents in real water samples are lacking. Most reported studies using synthetic PAC solutions did not also consider the effect of 
salts, organic matters, surfactants, inorganic molecules, etc., which influences the biosorption capacity or process. Therefore, more studies should be conducted to be able to know the exact capacity and prospects of biosorbents.

Table 3. Removal of PACs by some selected biosorbents and their sorption capacity.

\begin{tabular}{|c|c|c|c|c|c|c|c|}
\hline Biosorbent & PACs & $\begin{array}{l}\text { Adsorption } \\
\text { Capacity } \\
\left(\mathrm{mg} \mathrm{g}^{-1}\right)\end{array}$ & $\begin{array}{l}\text { Kinetic } \\
\text { Model }\end{array}$ & Mechanism & $\begin{array}{c}\mathrm{pH} \\
\text { Used }\end{array}$ & $\begin{array}{c}\text { Con } \\
\left(\mathrm{mg} \mathrm{L}^{-1}\right)\end{array}$ & Reference \\
\hline $\begin{array}{l}\text { Rice husk } \\
\text { ash }\end{array}$ & Tetracycline & 8.37 & PS & Complexation & $>7.7$ & $5-20$ & {$[71]$} \\
\hline $\begin{array}{l}\text { Potato } \\
\text { peel waste } \\
\text { (activated } \\
\text { carbon) }\end{array}$ & Diclofenac & 74.00 & PS & $\begin{array}{l}\pi-\pi \text { electron } \\
\text { donor-acceptor } \\
\text { interaction }\end{array}$ & 5 & $0-100$ & [72] \\
\hline Vine wood & $\begin{array}{l}\text { Amoxicillin, } \\
\text { Cephalexin, } \\
\text { Tetracycline and } \\
\text { Penicillin G }\end{array}$ & $1.98-8.41$ & PS & - & 2 & $20-200$ & [73] \\
\hline $\begin{array}{l}\text { Bamboo } \\
\text { biochar }\end{array}$ & $\begin{array}{l}\text { Sulfamethazine, } \\
\text { sulfamethoxazole, } \\
\text { and } \\
\text { sulfathiazole }\end{array}$ & $25.11-40.11$ & PS & $\begin{array}{l}\text { Lewis acid-base } \\
\text { interactions, } \\
\text { hydrogen bonding } \\
\text { and } \pi-\pi \\
\text { Electron-donor-acceptor } \\
\text { interactions }\end{array}$ & $3-6.5$ & $1-50$ & {$[74]$} \\
\hline Rice husk & Tetracycline & 3.89-13.85 & - & $\begin{array}{l}\pi-\pi \text { electron-donor } \\
\text { acceptor }\end{array}$ & 5.5 & $0.5-32$ & [75] \\
\hline $\begin{array}{l}\text { Reed } \\
\text { straw }\end{array}$ & Sulfamethoxazole & 23.35 & - & $\begin{array}{l}\text { Hydrogen bonding } \\
\text { and } \pi-\pi \text { electron } \\
\text { donor-acceptor }\end{array}$ & 4 & $5-30$ & [76] \\
\hline Date palm & Ciprofloxacin & $25.30-53.20$ & PS & $\begin{array}{l}\text { Cation exchange } \\
\text { and hydrogen } \\
\text { bonding }\end{array}$ & 6 & $50-300$ & [77] \\
\hline $\begin{array}{c}\text { Canola } \\
\text { biomass }\end{array}$ & Metronidazole & 21.42 & PS & $\begin{array}{c}\text { Electrostatic } \\
\text { interaction }\end{array}$ & 7 & $0-100$ & [78] \\
\hline $\begin{array}{l}\text { Groundnut } \\
\text { shell }\end{array}$ & Paracetamol & 3.02 & - & - & - & $10-100$ & [79] \\
\hline $\begin{array}{l}\text { Brassica } \\
\text { nigra }\end{array}$ & Acetic acid & 0.96 & - & - & - & $0.5^{*}$ & [80] \\
\hline
\end{tabular}

Table 4 presents the BET (Brunauer-Emmett-Teller) surface area obtained for some biosorbents. The value varies for the different adsorbents depending on the modification process. Plant materials, which are lignocellulose, have low $\mathrm{S}_{\mathrm{BET}}$ as shown by Silva et al. [81], which demonstrated that plant waste-based biosorbents are feasible alternatives to commercial adsorbents for the removal of PACs in solution. The team reported use of $\mathrm{NaOH}$ modified spent coffee grounds, pine bark and cork waste for the removal of fluoxetine from the water with biosorption capacities ranging from 4.74 to $14.31 \mathrm{mg} \mathrm{g}^{-1}$. The sorption capacities exhibited by commercially prepared materials, activated carbon $\left(233.5 \mathrm{mg} \mathrm{g}^{-1}\right)$, zeolite $13 \times\left(32.11 \mathrm{mg} \mathrm{g}^{-1}\right)$ and zeolite $4 \mathrm{~A}\left(21.86 \mathrm{mg} \mathrm{g}^{-1}\right)$ were higher than those of spent coffee grounds $\mathrm{G}\left(14.31 \mathrm{mg} \mathrm{g}^{-1}\right)$, pine bark $\left(6.53 \mathrm{mg} \mathrm{g}^{-1}\right)$, and cork waste $\left(4.74 \mathrm{mg} \mathrm{g}^{-1}\right)$. However, the $\mathrm{NaOH}$ modified biosorbents reflect economic feasibility through cost analysis $\left(0.16-6.85 € \mathrm{~g}^{-1}\right)$ as they are cheaper than the commercial materials, zeolite $4 \mathrm{~A}\left(6.85 € \mathrm{~g}^{-1}\right)$, zeolite $13 \times\left(3.13 € \mathrm{~g}^{-1}\right)$ and activated carbon $\left(1.07 € \mathrm{~g}^{-1}\right)$. Apart from economic feasibility, the biosorbents have a positive environmental impact by not introducing solid or liquid waste into the environment. As a form of chemical modification, $\mathrm{NaOH}$-activated carbon was prepared from macadamia nutshell for the removal of tetracycline from the water system [82]. The material showed a microporous structure with a BET 
surface area of $1524 \mathrm{~m}^{2} \mathrm{~g}^{-1}$. It exhibited an adsorption capacity of $455.33 \mathrm{mg} \mathrm{g}^{-1}$ towards tetracycline in a process that can be described by the Elovich kinetic model. The capacity was higher than what was reported for rice husk ash [71]. It has become obvious that antibiotics are the most studied classes of PACs with respect to biosorption onto newly sourced biosorbents. This might be because they are the most commonly found in the surface water system and due to the possibility of the emergence of drug-resistant microorganisms. Ciprofloxacin, tetracycline and sulfamethoxazole are among the most reported. The PACs and biosorbents exist in different ionic states (neutral, cationic or anionic) as $\mathrm{pH}$ changes. The different states of existence determine their speciation, and thus their $\pi$-electron-donating behavior, hydrophobicity and PAC-biosorbent interaction. Biosorption is most favourable when the PAC and biosorbent have different surface charges, which promotes electrostatic interaction. It is important to understand state of existence when designing and planning the removal of PACs in water systems. Study on date palm (Phoenix dactylifera) by El-Shafey et al. [77] revealed its capacity to adsorb ciprofloxacin from aqueous media by a sorption mechanism that is mainly related to cation exchange and hydrogen bonding. Previous studies have shown that modified plant-sourced material can exhibit both biosorption and photocatalysis. In this case, the surface of the material breaks down the PACs into smaller molecules and, at the same time, adsorbs. This observation was reported for reed straw supported titanium dioxide, which used synthesis by sol-gel method and was applied for the removal of sulfamethoxazole [76]. The material exhibited both biosorption and photocatalysis properties toward sulfamethoxazole with an adsorption capacity of $23,347 \mathrm{mg} \mathrm{g}^{-1}$, which can be described by Langmuir isotherm. Similarly, Kumar et al. [83] demonstrated the degradation and biosorption of ibuprofen and 2,4-dichlorophenoxyacetic acid using biochar. The degradation was monitored using LC-MS (Liquid chromatography-mass spectrometry) while the toxicity of the degraded products was analyzed by the viability of human peripheral blood cells. This has also shown that biosorbents modified with transition metal salts like Ti, $\mathrm{Zn}$, etc., have the capacity to degrade the PACs, apart from the biosorption of the PACs taking place at the surface of the biosorbent. It is of note that most reported degradation processes did not lead to complete degradation to $\mathrm{CO}_{2}$ and $\mathrm{H}_{2} \mathrm{O}$. Biosorbents of this class are considered dual-functional because of their ability to exhibit both biosorption and degradation in a single process of water treatment.

Other studies have also shown that biomaterial could be incorporated with nanomaterials to improve on performance. Wang et al. [84] reported this in a study on the removal of ciprofloxacin from aqueous solution by magnetic chitosan grafted graphene oxide. The material exhibited a high sorption capacity of $282.9 \mathrm{mg} \mathrm{g}^{-1}$; the process was $\mathrm{pH}$-dependent. The authors further reported the influence of other ions ( $\mathrm{Ca}$ and $\mathrm{Na}$ ), which was significant on the sorption of ciprofloxacin in a process controlled by electrostatic attraction and $\pi-\pi$ electron interaction. It has become so obvious that functionalization plays an important role in improving the ability of plant-sourced materials to perform significantly as biosorbents. The authors reported the synthesis of magnetic chitosan grafted graphene oxide nanocomposite as an efficient biosorbent for the removal of ciprofloxacin. The modification led to a reduction in the surface area of graphene oxide from $1685.7 \mathrm{~m}^{2} \mathrm{~g}^{-1}$ to $388.3 \mathrm{~m}^{2} \mathrm{~g}^{-1}$ due to aggregation resulting from chitosan. The average pore diameter was $13.98 \mathrm{~nm}$, which suggested that the biosorbent composite was a mesoporous material. This also revealed that care must be taken when selecting a chemical modification method in order to prevent the selection of methods or steps that may lead to the formation of aggregates, which reduces the surface area. Since both Langmuir and Freundlich isotherms can describe the process, the authors argued that the process of biosorption was likely to be a complex chemisorption process. The bio-composite was regenerated using $100 \%$ methanol; the performance was above $80 \%$ in the first cycle. However, the biosorption capacity remained at $72 \%$ at 4 th regeneration. Unfortunately, most authors did not report the regeneration of biosorbents in their studies. Attention should be given to regeneration studies to understand the worth of low-cost biosorbents. 
Table 4. Mode of study, $\mathrm{S}_{\mathrm{BET}}$, Isotherm, $\mathrm{Qe}$, Isotherm, Desorption and $\Delta \mathrm{G}^{\circ}$ for the sorption of PACs on biosorbents.

\begin{tabular}{|c|c|c|c|c|c|c|c|c|}
\hline Biosorbent & PAC & $\begin{array}{l}\text { Mode of } \\
\text { Study }\end{array}$ & $\begin{array}{c}\mathrm{S}_{\mathrm{BET}} \\
\left(\mathrm{m}^{2} \mathrm{~g}^{-1}\right)\end{array}$ & $\begin{array}{c}\mathrm{Qe} \\
\left(\mathrm{mg} \mathrm{g}^{-1}\right)\end{array}$ & Isotherm & $\begin{array}{l}\text { Desorption } \\
(\%)\end{array}$ & $\begin{array}{c}\Delta \mathrm{G}^{\circ} \\
\left(\mathrm{kJ} \mathrm{mol}^{-1}\right)\end{array}$ & Reference \\
\hline CA-Al-KABs & Ciprofloxacin & Batch & 10.595 & 68.36 & Langmuir & - & -0.944 & [32] \\
\hline $\begin{array}{c}\text { SCG } \\
\text { CW } \\
\text { PB }\end{array}$ & Fluoxetine & Batch & $\begin{array}{l}<4 \\
<4 \\
<4\end{array}$ & $\begin{array}{c}14.31 \\
4.74 \\
6.53\end{array}$ & Sips & - & - & [81] \\
\hline MNS & Tetracycline & Batch & 1524 & 455.33 & Temkin & - & - & [82] \\
\hline MCGO & Ciprofloxacin & & 388.3 & 282.9 & $\begin{array}{l}\text { Freundlich } \\
\text { and } \\
\text { Langmuir }\end{array}$ & $>80$ & - & [84] \\
\hline WPK & Naproxen & Batch & 601.9 & $\begin{array}{c}73.14 \\
174\end{array}$ & Langmuir & - & - & {$[85]$} \\
\hline $\begin{array}{l}\text { GS } \\
\text { YB } \\
\text { CB }\end{array}$ & Paracetamol & Batch & $\begin{array}{l}- \\
- \\
-\end{array}$ & $\begin{array}{l}1.11 \\
0.77 \\
0.99\end{array}$ & Langmuir & - & - & [86] \\
\hline CTCBW & \multicolumn{2}{|c|}{$\begin{array}{l}\text { Acetaminophen Batch } \\
\text { Clarithromycin }\end{array}$} & 80.586 & - & Freundlich & - & & [87] \\
\hline СBP & $\begin{array}{l}\text { Clarithromycir } \\
\text { Atenolol }\end{array}$ & & 19.26 & $\begin{array}{l}34.5 \\
39.5\end{array}$ & $\begin{array}{l}\text { Freundlich } \\
\text { Langmuir }\end{array}$ & - & -838 & [88] \\
\hline ASCK & $\begin{array}{l}\text { Paracetamol } \\
\text { Amoxicillin }\end{array}$ & $\begin{array}{l}\text { Batch and } \\
\text { fixed bed }\end{array}$ & 1908 & $\begin{array}{l}502.26 \\
282.42\end{array}$ & $\begin{array}{l}\text { L-F } \\
\text { L-F }\end{array}$ & - & - & [89] \\
\hline ASK & $\begin{array}{l}\text { Paracetamol } \\
\text { Amoxicillin }\end{array}$ & $\begin{array}{l}\text { Batch and } \\
\text { fixed bed }\end{array}$ & 1635 & $\begin{array}{l}453.39 \\
228.39\end{array}$ & $\begin{array}{l}\text { L-F } \\
\text { L-F }\end{array}$ & - & - & [89] \\
\hline ASP & $\begin{array}{l}\text { Paracetamol } \\
\text { Amoxicillin }\end{array}$ & $\begin{array}{l}\text { Batch and } \\
\text { fixed bed }\end{array}$ & 420 & $\begin{array}{l}318.84 \\
198.73\end{array}$ & $\begin{array}{l}\text { L-F } \\
\text { L-F }\end{array}$ & - & - & [89] \\
\hline
\end{tabular}

CA-Al-KABs = Aluminum-pillared kaolin sodium alginate beads, $\Delta \mathrm{G}^{0}=$ Free Gibbs energy, $C W=$ Cork waste, $\mathrm{PB}=$ Pine bark, $\mathrm{SCG}=$ Spent coffee grounds, $\mathrm{MNS}=$ macadamia nut shells, $\mathrm{MCGO}=$ Magnetic chitosan grafted graphene oxide nanocomposite, WPK = Wild plum kernels, GS = Grape stalk, YB = Yohimbe bark, CB = Cork bark, CTCBW $=$ Chemically treated chicken bone waste, $\mathrm{CBP}=$ Cuttlefish bone powder, $\mathrm{ASCK}=\mathrm{NaOH}$ modified Argan waste carbon, $\mathrm{ASK}=\mathrm{NaOH}$ modified Argan waste, ASP $=$ Phosphoric acid modified Argan waste, $\mathrm{L}-\mathrm{F}=$ Langmuir-Freundlich isotherm, $\mathrm{S}_{\mathrm{BET}}=$ Surface area .

Recently, a study by Paunovic et al. [85] documented microwave-functionalized biochar derived from novel lignocellulosic waste biomass for the sorption of ionizable emerging pharmaceuticals in solution. They achieved this by preparing a functionalized biochar from wild plum kernels using simultaneous pyrolysis and microwave potassium hydroxide functionalization. The material removed naproxen from solution at a $\mathrm{pH}$ 5-7 having a maximum adsorption capacity of $73.14 \mathrm{mg} \mathrm{g}^{-1}$. The removal was driven by electrostatic attraction as the main mechanism of the process, as shown in Figure 2. Chemical modification by way of first converting biomass to biochar before it is chemically activated or functionalized has received attention for the removal of PACs in a water system. More recently, microwave-assisted techniques have been gaining relevance because of their advantage over the conventional pyrolysis method. Biosorbents prepared through this method have a higher surface area as reported by Paunovic et al. [85] when compared with other direct, simple modifications as reported by Silva et al. [81] in Table 4. The microwave-assisted method is of advantage because the conventional pyrolysis method involves heat transfer to the biomass particles by convection, conduction and radiation mechanisms. During the conventional method, the surface of the biomass is heated first in comparison with the internal zones, resulting in a temperature gradient from the biomass surface to the interior of each particle. The method requires high temperatures, meaning high-energy involvement, which makes it expensive to run. However, the microwave-assisted methods make use of radiation that utilizes volumetric heating within a short time. A relatively low amount of energy is required; the processing time is short with high production yield, which makes it cheaper than the conventional pyrolysis method. The surface area of natural biosorbents has been improved via this means as a way of enhancing sorption capacity for PACs. 

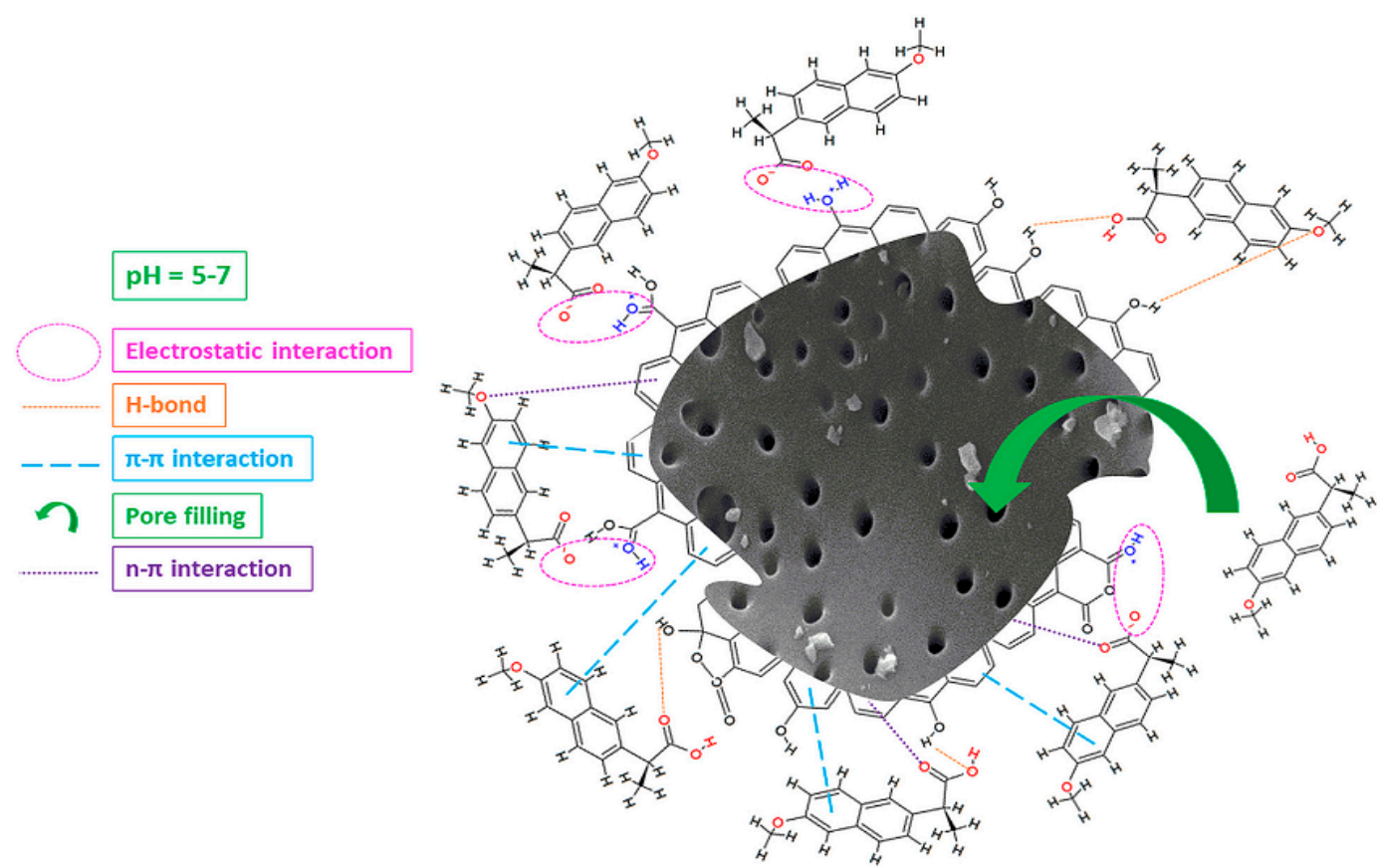

Figure 2. Proposed key sorption mechanisms for the sorption of naproxen on microwave-functionalized biochar [85].

Use of plant waste after simple pretreatment have also been reported. An example of this is the use of grape stalk, yohimbe bark, and cork bark for the removal of paracetamol reported by Villaescusa et al. [86]. The removal process was found not to depend on $\mathrm{pH}$. The grape stalk waste exhibited the best adsorption capacity with a modelling capacity that reflected $\pi$-stacking interactions among the lignin, syringyl and guaiacyl moieties in grape stalk and the aromatic ring in paracetamol. Adewuyi et al. [90] also reported the pretreatment of Adenopus breviflorus for the removal of 2-chlorophenol in solution. The pretreatment was achieved using different solvent systems. The treatment prevented the introduction of organic molecules from the seed biosorbent into the treated solution in a process which followed the pseudo-second-order model, with isotherm plots fitting well for Freundlich, Langmuir and Temkin models.

Animal waste such as fish bones, cow bones, crab shells, eggshells, etc., have been explored as biosorbents or precursor materials for biosorption. The study by Kizilkaya et al. [91] reported pretreated fish bones obtained from bluefish (Pomatomus saltotrix), bogue (Boop boops), European anchovy (Engraulis encrasicolus) and gilthead seabream (Sparus aurata) as low-cost biosorbents. Dahiya et al. [92] also reported the use of pretreated crab and arca shell biomass for biosorption. Ojedokun and Bello [93] published a review on the use of cow dung as biosorbent for the removal of pollutants in water. This has shown an affinity for cations, which suggests that the material may be useful for the removal of positively charged PACs in solution. The review showed cow dung as a bioorganic waste, eco-friendly and inexpensive biosorbent. Previous studies $[93,94]$ showed cow dung to contain calcium sulphate $(0.312 \%)$, aluminum oxide $(20 \%)$, calcium oxide $(12.48 \%)$, magnesium oxide $(0.9 \%)$, iron oxide $(20 \%)$ and silica (61\%). Another study by El Haddad et al. [95] revealed the use of animal bone meal as biosorbent for the removal of organic compounds in water. The material had an adsorption capacity of $57.15 \mathrm{mg} \mathrm{g}^{-1}$ towards reactive yellow 84 dye in a process that is endothermic, and that can be described by Langmuir isotherm. Dyes and PACs are organic molecules; the ability of the material to remove yellow 84 dye in solutions is an indication that the material may be useful for the removal of organic molecules like PACs in solution. Previous work [87] has reported the use of chemically modified chicken bone waste as a biosorbent efficient for the removal of acetaminophen. The process fitted well for both pseudo-second-order kinetic and Freundlich isotherm models. Interestingly, a mixture of activated animal bones from cow, donkey, chicken and horse has also been evaluated as an efficient biosorbent for 
wastewater treatment [96]. Use of human hair as a biosorbent for the removal of phenol was reported to achieve a removal of $92 \%$ in a batch process [97]. The study leveraged on the fact that human hair contains keratin, which is a fibrous proteinaceous material with a large surface area. It reveals the ability of human hair as a possible means for the removal of micro-organic pollutants such as PACs in water. It is a pointer towards finding application for human hair waste produced in large quantities in barbers, serving as a means of converting waste to wealth. Clarithromycin and atenolol, which are common PACs in surface water, were reportedly biosorbed onto cuttlefish bone powder treated with $\mathrm{HCl}$ [88]. The biosorbent showed an adsorption capacity of $34.5 \mathrm{mg} \mathrm{g}^{-1}$ towards clarithromycin and $39.5 \mathrm{mg} \mathrm{g}^{-1}$ towards atenolol in a process that was found to be spontaneous. The $\Delta \mathrm{G}^{\circ}$ for the process was negative $\left(-838 \mathrm{~kJ} \mathrm{~mol}^{-1}\right)$, which suggests that the process was spontaneous. A similar negative value $\left(-0.944 \mathrm{~kJ} \mathrm{~mol}^{-1}\right)$ was reported for the sorption of ciprofloxacin on CA-Al-KABs [32]. However, most recent works found in the literature did not consider the effect of temperature on the biosorption of PACs. Most of the published works on biosorption of PACs were carried out focusing on batch operation mode under agitation, which created a gap for limited fixed-bed mode and pilot studies. This makes it difficult to better estimate the potential of biosorbents. It was also evident that most studies did not compare the capacity of the considered low-cost biosorbents with commercially available materials for effective comparison. It is important that future studies consider this.

\subsection{Microorganisms as Biosorbents}

At the early stage of involving microorganisms in the biosorption process, the effort by researchers revealed that inactive/dead microbial biomass could passively bind metal ions. The dead microbial biomass has several advantages over the living microbial biomass such as being cheap, limitation of toxicity, ease of regeneration, exhibiting ion exchange and with a wide range of operational $\mathrm{pH}$ and temperature. Subsequently, the effort began to move towards investigating the removal of dyes and other organic pollutants in the water system. Over time, it became evident that biosorption exhibited by microbial biomass does not only depend on the chemical composition of the microbial biomass but also the external physicochemical factors and the matrix chemistry. This mechanism has been reported to be one or a combination of chelation, complexation, adsorption, ion exchange, degradation, electrostatic interaction, microprecipitation, coordination and donor-acceptor interaction [52,98]. Strains of microorganisms have been shown with the capacity to bio-transform toxic compounds into less hazardous forms [99]. The sorption tendency exhibited by a microorganism further depends on the microbial genus, which on the long run defines its cellular composition. They can be used in the form of fine powder or wet cells, which makes resistance to mass transfer negligible. Some biomass has been tested and reported as biosorbent. They include algae, yeast, bacteria and fungi with well-defined structures.

\subsubsection{Bacterial}

Based on the cell wall and gram staining, bacteria can be divided into Gram-negative and Gram-positive. The cell ranged in diameter between 0.5 to $1.0 \mu \mathrm{m}$, and most are unicellular, belonging to the prokaryotes. The cell has four major components: cytoplasm, cell wall, nuclear and cell membrane. The proportions of lipid and protein in the cell membrane vary from one species to the other. They have different shapes such as spiral, rod, cocci and filamentous. The cell wall differs from those of other microorganisms due to the presence of peptidoglycan, which determines its shape and the rigidity of the cell wall. A description of the cell wall of Gram-positive and negative bacterial is shown in Figure 3. 


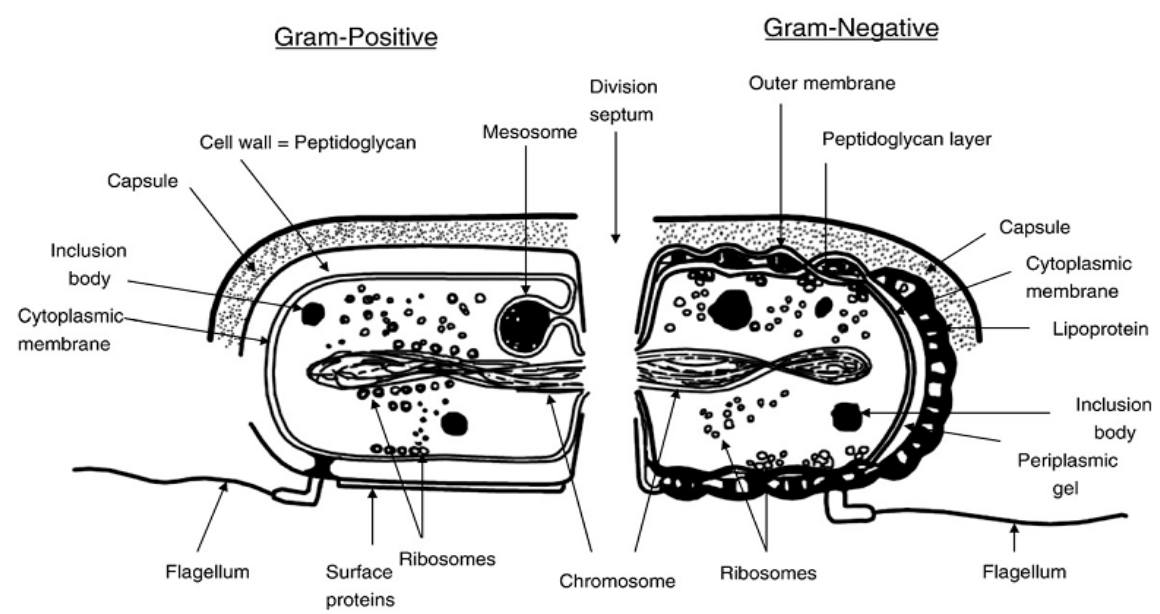

Figure 3. Structure of Gram-positive and negative s [52].

During biosorption by bacteria, the cell wall encounters the PACs first in an interaction where PACs are deposited on its surface. The functional groups such as amine, hydroxyl, carboxyl and phosphonate groups of the cell wall play an important role in the biosorption process since the uptake of the PACs is extracellular [52,100]. Characterization and the biosorption mechanism of bacteria have been studied using different methods such as X-ray diffraction, potentiometric titrations, scanning electron microscopy, Fourier transform infrared spectroscopy, transmission electron microscopy and energy dispersive X-ray microanalysis [101-104]. This has revealed the types, nature and number of binding sites on the surface of the bacteria. Use of Fourier transform infrared spectroscopy has shown band transformations, which enabled the prediction of possible functional groups involved in the biosorption, as well as the acidity and basicity of the bacterial surface involved in the interaction. Energy-dispersive X-ray microanalysis had helped in predicting the chemical and elemental composition of the bacterial, which helps in confirming the involvement of ion exchange mechanism during the biosorption process. X-ray diffraction analysis helps in predicting the chemical nature, while the morphology of the cell surface can be studied using scanning electron microscopy. Both the surface chemistry of the biosorbent and the water chemistry plays an important role in the removal of PACs while certain factors such as solution $\mathrm{pH}$, ionic strength, particle size, concentration and temperature influences the removal rate as well as the adsorption capacity of the bacterial.

Studies have reported different means of enhancing the capacity of bacterial to act as biosorbents. Methods include chemical and genetic modification. Some focused on improving the active binding sites to improve biosorption capacity while less consideration was given to the inhibition sites on the surface of the bacteria. A study by Vijayaraghavan and Yun [105] revealed that the amine group are active towards biosorption of organic compounds via electrostatic interaction. However, on the contrary, the presence of carboxyl functional groups on the same surface repels biosorption from taking place at the surface. The study by Martins et al. [106] reported the use of anaerobic microorganisms to remove ciprofloxacin, $17 \beta$-estradiol and sulfamethoxazole from solution as well as elucidate their bio-removal mechanisms. The work provided new insight into the anaerobic bioremediation of ciprofloxacin, $17 \beta$-estradiol and sulfamethoxazole. During the process condition used (nitrate- and sulfate-reducing conditions), ciprofloxacin was biodegraded to $80 \%$ under both conditions. Degradation of $17 \beta$-estradiol reached $84 \%$ under nitrate-reducing conditions whereas no biodegradation was achieved with respect to sulfamethoxazole. The study further revealed that bioremediation might occur by four mechanisms: (i) extracellular bio-removal by metabolites produced during growth, (ii) biodegradation by co-metabolism, (iii) biodegradation by sole substrate consumption, or (iv) biosorption to the bacterial cells. Sorption steps and biodegradation characteristics of lomefloxacin, ofloxacin, enrofloxacin, ciprofloxacin and norfloxacin have been reported [107]. The study reported sorption of these PACs as the lead process followed by biodegradation. The biodegradation was favored under aerobic condition 
by temperature increase, which may have been achieved during nitrification through co-metabolism. Co-metabolic activities of heterotrophic denitrifying bacteria and ammonia-oxidizing bacteria in the removal of nitrogen and pharmaceutical and personal care products have been investigated [108]. The study revealed biodegradation as the dominant process for removal of ibuprofen while removal of triclosan was via an equal contribution from adsorption and biodegradation.

Commonly used bacterial strains for remediation of wastewater include Pseudomonas, Enterobactor, Streptomonas, Aeromonas, Acinetobactor and Klebsiella. Several membrane bioreactors have been developed for large-scale treatment of domestic and industrial wastewater.

Use of membrane reactor has shown several advantages such as flexibility in operation, prolonged microorganism retention, complete removal of suspended solids, low rate of sludge production, treatment of both toxic inorganic and organic pollutants, compact plant size and high rate of degradation [109]. E-coli biofilm built on activated carbons was reported [89] for the removal of paracetamol and amoxicillin present in water. The prepared material is microporous with a high surface area. The performance of the material was compared with when the E-coli biofilm was not built into the activated carbon. The sorption process without the biofilm showed a rapid kinetic, with sorption capacity being $319 \mathrm{mg} \mathrm{g}^{-1}$ in a process that can be described by Langmuir isotherm. Interestingly, the process changed significantly when the biofilm was introduced to the activated carbon. Although the kinetic was slow, the performance changed remarkably with the material exhibiting a biosorption capacity of $465 \mathrm{mg} \mathrm{g}^{-1}$ and the process best represented by Langmuir-Freundlich isotherm model having three different stages. This has shown that the use of bacteria in the biosorption process for the removal of PACs in water has a positive impact. As shown in Table 4, the authors focused on the removal of paracetamol and amoxicillin. They argued that the size of PAC plays an important role in its removal; in this case, paracetamol has a lower molecular weight $\left(151.16 \mathrm{~g} \mathrm{~mol}^{-1}\right)$ compared to amoxicillin (365.4 $\mathrm{g} \mathrm{mol}^{-1}$ ), which may have contributed to the greater sorption capacity exhibited towards paracetamol in the study.

\subsubsection{Fungi}

This includes yeasts and molds. They are filamentous, with mycelium, which contains a complex mass of filaments. The cell wall is rigid, which gives structural support and shape, mainly consisting of polysaccharide, with polyphosphates, proteins, lipids and inorganic ions. The composition of the cell wall may have contributed significantly to its use as biosorbent for the removal of PACs. Fungi have a promising ability to serve as biosorbents because of its various functional groups, due to the high amount of cell wall materials. It is readily available due to the ease of cultivation in large scale with high yield. Previous work has shown that the use of yeast for environmental research is attractive because it can be genetically modified. It is well characterized, which helps in understanding the biosorption mechanism. The ease of modification shows that it can be manipulated for removing PACs in solution. Four factors that can influence the biosorption of fungi have been reported as: biomass dose in solution, type and nature of biomass, physicochemical factors like temperature, $\mathrm{pH}$, ionic strength, and initial solute concentration [110]. They can be modified chemically or physically to improve capacity to act as biosorbent. The modification can be achieved via improving surface characteristics by exfoliating or masking the functional groups or by making the biosorption sites readily available for sorption [111,112]. They are pretreated chemically to modify the cell wall by creating derivatives with altered sorption abilities and affinities [112]. When fungi are used in water treatment, the free cells have small particle size and low mechanical strength, which creates the need for the application of hydrostatic pressure for a suitable flow rate. However, this leads to disintegration and attrition. Although this material might work well when subjected to the batch process, due to the hydrostatic pressure they become unsuitable for the column packing process, which is applicable in the industrial process [113]. Due to the disintegration and attrition challenge, immobilization techniques have been recommended as means of modification, which may include crosslinking and entrapment. 
When this takes place on polymeric matrix, the biosorbent exhibits improvement and advantage in particle size, high biomass loading, minimal clogging, high regeneration and ease of separation [114].

Table 5 shows the different types of fungi reported in the past for the removal of PACs in water. As shown in the table, it is evident that when using fungi for water treatment, biosorption and biodegradation mostly take place together.

Table 5. Selected fungi previously reported for the removal of PACs.

\begin{tabular}{|c|c|c|c|}
\hline PACs & Fungi & $\begin{array}{l}\text { Mechanism of } \\
\text { Action }\end{array}$ & Reference \\
\hline $\begin{array}{c}\text { Estrone, } 17 \\
\beta \text {-estradiol, } 17 \\
\alpha \text {-ethinyl-estradiol and } \\
\text { estriol }\end{array}$ & $\begin{array}{c}\text { Myceliophthora thermophile and } \\
\text { Trametes versicolor }\end{array}$ & $\begin{array}{l}\text { Biodegradation } \\
\text { Adsorption }\end{array}$ & [115] \\
\hline Carbamazepine & Phanerochaete chrysosporium & $\begin{array}{l}\text { Biodegradation } \\
\text { Biosorption }\end{array}$ & [116] \\
\hline $\begin{array}{l}\text { Sulfapyridine, } \\
\text { sulfapyridine, and } \\
\text { sulfamethazine }\end{array}$ & Trametes versicolor & $\begin{array}{l}\text { Biodegradation } \\
\text { Biosorption }\end{array}$ & [117] \\
\hline $\begin{array}{l}\text { Diclofenac, ibuprofen, } \\
\text { naproxen, } \\
\text { carbamazepine, and } \\
\text { diazepam }\end{array}$ & Phanerochaete chrysosporium & $\begin{array}{l}\text { Biodegradation } \\
\text { Biosorption }\end{array}$ & [118] \\
\hline $\begin{array}{c}\text { Carbamazepine, } \\
\text { diclofenac, iopromide } \\
\text { and venlafaxine }\end{array}$ & $\begin{array}{c}\text { Trametes versicolor } \\
\text { Irpex lacteus } \\
\text { Ganoderma lucidum } \\
\text { Stropharia rugosoannulata } \\
\text { Gymnopilus luteofolius } \\
\text { Agrocybe erebia }\end{array}$ & Biosorption & [119] \\
\hline
\end{tabular}

Sorption of carbamazepine, diclofenac, iopromide and venlafaxine by fungi was reported in a bioreactor treatment [119]. The sorption process was likened to active transport in living cells, which plays an essential role in the sorption process. The removal of the PACs was by both sorption and biodegradation. Recently, Aspergillus sydowii and Aspergillus destruens were reported for their use under saline conditions for the removal of PACs [120]. Benzo- $\alpha$-pyrene and phenanthrene were used as a sole carbon source during the study. They achieved a removal of over $90 \%$ in a process described to be biodegradation (Aspergillus sydowii) and biosorption (Aspergillus destruens). Furthermore, a study [121] on the efficiency of Trametes versicolor and Ganoderma lucidum, to remove thirteen pharmaceutical pollutants with concomitant biodiesel production from the accumulating lipid content after treatment, revealed a $100 \%$ removal for diclofenac, gemfibrozil, ibuprofen, progesterone and ranitidine, whereas it showed low removal towards 4-acetamidoantipyrin, clofibric acid, atenolol, caffeine, carbamazepine, hydrochlorothiazide, sulfamethoxazole and sulpiride. However, the combination of Trametes versicolor and Ganoderma lucidum enhanced efficiency, which was attributed to the interactions developed between both strains. In general, white-rot fungi belonging to the Basidiomycota family has been used in several studies to evaluate potential as a means of removing PACs in water [115,122-125]. They are well known for their ability to degrade lignin. Interestingly, their enzyme system is based on free radicals; they are non-selective and non-specific; they tend to degrade pollutants either by extracellular or intracellular enzymatic route [126]. This capacity and mechanism of degrading lignin is also extended towards PACs. This ability gives them an outstanding edge and attraction in the treatment of wastewater. 


\subsubsection{Microalgae}

There is growing interest in the use of microalgae-based remediation biotechnologies as a means of removing PACs in water. The microalgae-based remediation biotechnology is green, driven by solar energy, eco-friendly, shows fixation and turnover of carbon, and can serve as a source of other useful products $[127,128]$. Figure 4 a shows the different species of microalgae commonly used in bioremediation of wastewater and PACs [129]. The fact that mixotrophic microalgae can maneuver their metabolism process between autotrophic and heterotrophic, making them survive and thrive in extreme environments, gives them an edge over bacteria and fungi that need carbon and other nutrients for growth and degradation of PACs. Just like bacterial and fungi, algae make use of their cell wall for the removal of PACs in solution. The cell wall contains several substances like lignin, pectins, protein, cellulose, hemicellulose and extensin. Due to the main functional groups in the cell wall being phosphoryl, amine and carboxyl groups, the cell wall is negatively charged, which makes them attractive towards cations via electrostatic interaction. Apart from the charge playing an essential role in biosorption, the hydrophobicity, species and structure are also crucial in selecting microalgae for biosorption activities. Studies have shown their ability to remove carbamazepine, ibuprofen, metoprolol, estrone, $\beta$-estradiol, etc., from solution. A report by Matamoros et al. [130] showed that mixed microalgae species such as Chlorella and Scenedesmus species could remove tris(2-chloroethyl) phosphate, caffeine, tributyl phosphate, carbamazepine, galaxolide, 4-octylphenol and ibuprofen from solution. The removal of the pollutant was high at a capacity that was not less than $99 \%$. However, the aerated batch reactors inoculated with the mixed microalgae could only efficiently remove 4-octylphenol, galaxolide, and tributyl phosphate as well as ibuprofen and caffeine, but expressed difficulties removing carbamazepine and tris(2-chloroethyl) phosphate. Interestingly, the authors argued that it was the first time that the enhancing effect of microalgae in water treatment had been evaluated. The findings showed that microalgae improved the removal efficiency of ibuprofen by $40 \%$, which further reduced the lag phase of caffeine by three days. It was further shown that microalgae improved the removal efficiency of ibuprofen and caffeine either by releasing exudates, which enhanced the biodegradation processes, or by microalgae biosorption. Studies of Scenedesmus obliquus and Chlorella pyrenoidosa dead cells have shown their ability to remove progesterone and norgestrel [131]. When PACs are biosorbed by microalgae, they can bioaccumulate with the possibility of causing damage to the cell; however, the concentration at which PACs are present in the environment is safe enough for the microalgae and do not exhibit lethal inhibition [129,132]. Chlamydomonas Mexicana and Scenedesmus obliquus are examples of species that bioaccumulated carbamazepine [133]. Microalgae have shown biodegradation to be an effective mechanism for the removal of PACs in water. They have biodegraded carbamazepine, ibuprofen, caffeine and tris(2-chloroethyl) phosphate in previous studies $[134,135]$. Several types of enzymatic reactions have been brought forward to describe the degradation exhibited by microalgae towards PACs, and some of these reactions include oxidation, ring cleavage, demethylation, hydroxylation, hydrogenation, carboxylation, halogenation, decarboxylation and glycosylation [129-135]. The degradation of PACs, as described in Figure 4b may occur in a two phase enzyme system known as phase I and II. In phase I, initial attacks take place using enzyme cytochrome P450, which increases the hydrophilicity of PACs or promote hydrolysis, reduction or oxidation reactions. During phase II reaction, enzymes such as glutathione-S-transferases catalyze the reaction between glutathione and electrophilic molecules; this reaction also protects the system against oxidative damage [129]. Escapa et al. [136] reported the removal of salicylic acid, paracetamol, phosphate and nitrate using Chlorella sorokiniana. This study further revealed its use for the biodegradation of metoprolol, diclofenac, paracetamol and ibuprofen. 

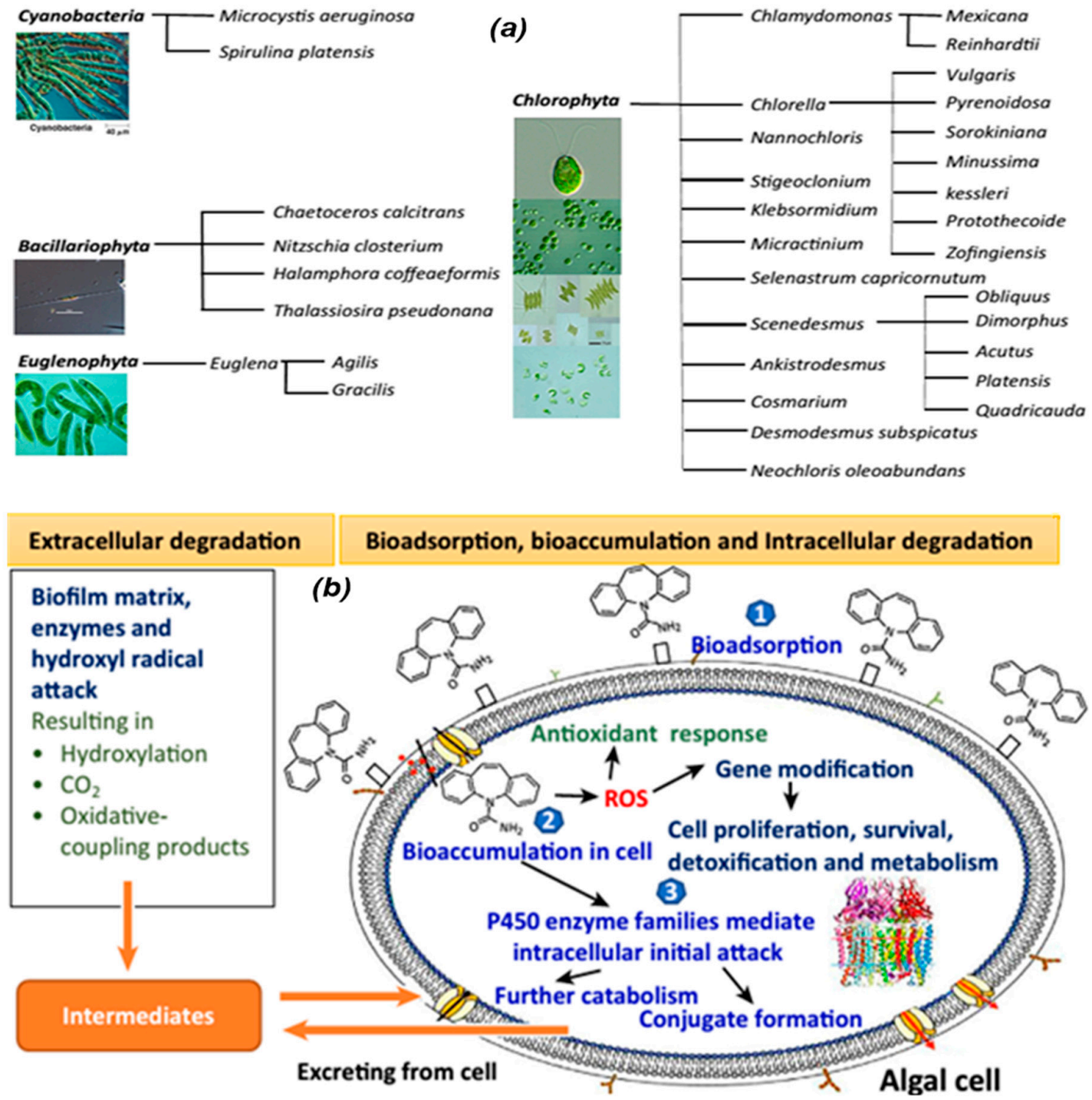

Figure 4. (a) Microalgae species commonly used for bioremediation of wastewater, (b) Proposed mechanisms of removal of pharmaceutical contaminants and microalgae metabolism [129]. ROS $=$ Reactive oxygen species.

The complete role of these enzymes in the two phase enzyme system is not well understood as research is currently ongoing on how to understand the biotransformation of PACs in the microalgae system. However, metagenomics and meta-transcriptomics analyses are playing a leading role in this regard. Co-metabolism has also been effective in enhancing the ability of microalgae in the removal of PACs. The introduction of organic substrates to the degradation process serves as a means of supporting activities of specific catabolic enzymes in charge of the degradation process. This was demonstrated in the degradation of monooxygenase and N-deethylase with the introduction of acetate [137]. It is important to evaluate the influence of organic substrate before it is introduced into the degradation process because some substrate is capable of having a negative effect on the process by reducing enzyme activity. However, a few factors are understood, such as the role of electron-donating groups, e.g., amine, hydroxyl and alkoxy, in enhancing susceptibility to electrophilic attack by enzymes. It has also become clear that the presence of groups such as nitro, halogen and amide decreases enzymatic biotransformation ability $[53,138]$. This is also an indication that it is better to understand the structure and functional group composition of PACs before selecting species of microorganisms for its removal. It is also essential to understand the functionality of any organic substrate before inclusion in the degradation process. 


\subsection{Biocomposite}

Bio-composites are materials containing two or more distinct substances, which are brought together to produce a new material with improved performance better than the individual constituent materials. They are biomass-based-materials that can be used for wastewater treatment; they are receiving much attention now because of their biodegradability, high performance and eco-friendliness. Biopolymers remain the major component of bio-composites; these biopolymers are cellulose, chitosan, starch, chitin, alginate, etc. The merit of these biopolymers lies in their non-toxicity, abundance, cost-effectiveness and environmental friendliness [139]. Cellulose, chitin and chitosan are similar in their chemical structure. The only difference is the $\mathrm{N}$-acetyl, amino and hydroxyl functional groups at the C-2 position, as shown in Figure 5.
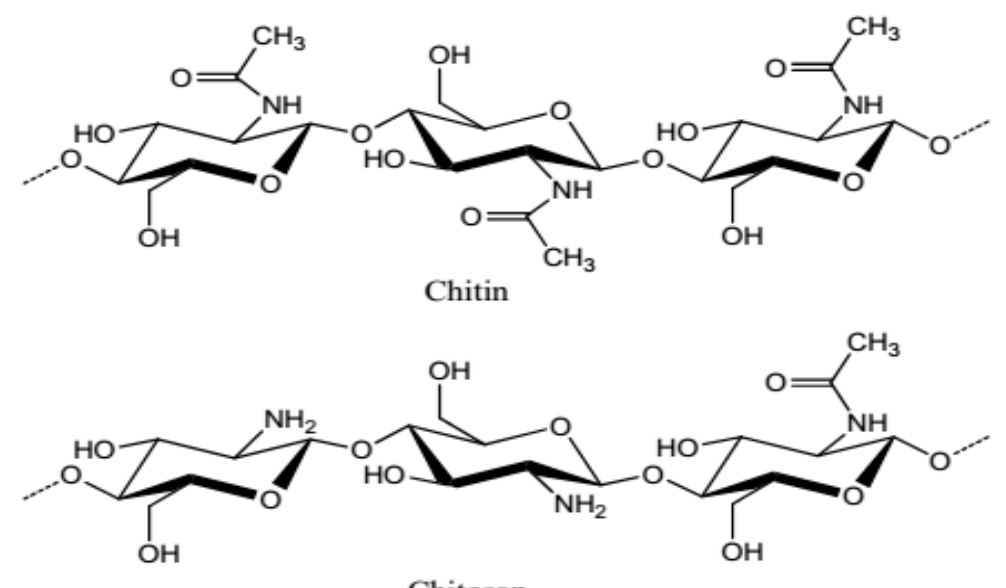

Chitosan

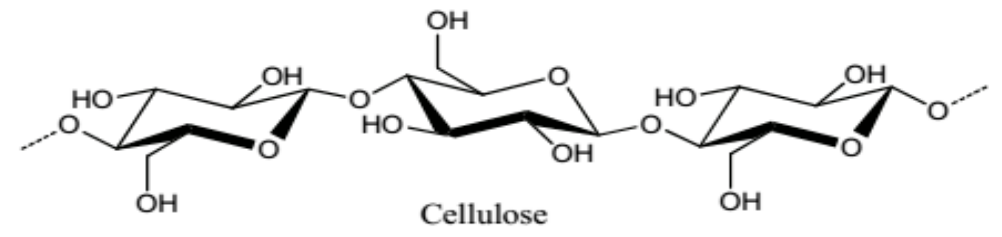

Figure 5. Structure of chitosan, chitin and cellulose [140].

These materials have been prepared in combination with other materials such as clay (commonly used clays include kaolinite, vermiculite, montmorillonite and illite), graphene, carbon, etc. Use of biopolymer alone may not be so effective in the removal of PACs from water. However, the combination of these materials (clay, carbon, graphene and natural polymer) plays an important role. Clay and graphene have large surface areas that can enhance removal; moreover, the cation exchange capacity of clays is also essential. An appropriate bio-composite should be inexpensive, abundant, efficient, environmentally friendly, biocompatible and reusable.

Table 6 presents different bio-composites reported in the literature. Karoui et al. [141] reported the preparation of enhanced biosorbent from Tunisian-reed (Phragmites-Australis) and its use in the removal of ciprofloxacin antibiotic and methylene blue dye. The composite was designed under response surface methodology. The study revealed a $76.66 \%$ removal for ciprofloxacin and $100 \%$ removal for methylene blue dye in a process that can be described by the Brouers-Sotolongo-fractal model. A study reported the removal of parabens from wastewater using magnetic waste tyre activated carbon-chitosan composite [142]. The composite has a surface area of $1281 \mathrm{~m}^{2} \mathrm{~g}^{-1}$ and pore size of $4.05 \mathrm{~nm}$, which exhibited a high sorption capacity with $100 \%$ removal in a process described by Langmuir and Redlich-Peterson isotherm models. Figure 6 shows the adsorption of parabens and the TEM (Transmission electron microscopy) images. The composite contains chitosan, which is the most deacetylated form of chitin. The presence of hydroxyl and amine groups makes it highly reactive 
with other compounds. The regeneration capacity of the biosorbent was carried out using methanol. The results obtained for the regeneration showed that recovery and adsorption were not affected for up to seven adsorption/desorption cycles. The result of the regeneration demonstrated the outstanding reusability of the bio-composite and its potential use in wastewater treatment.

Table 6. Bio-composites reported for water treatment.

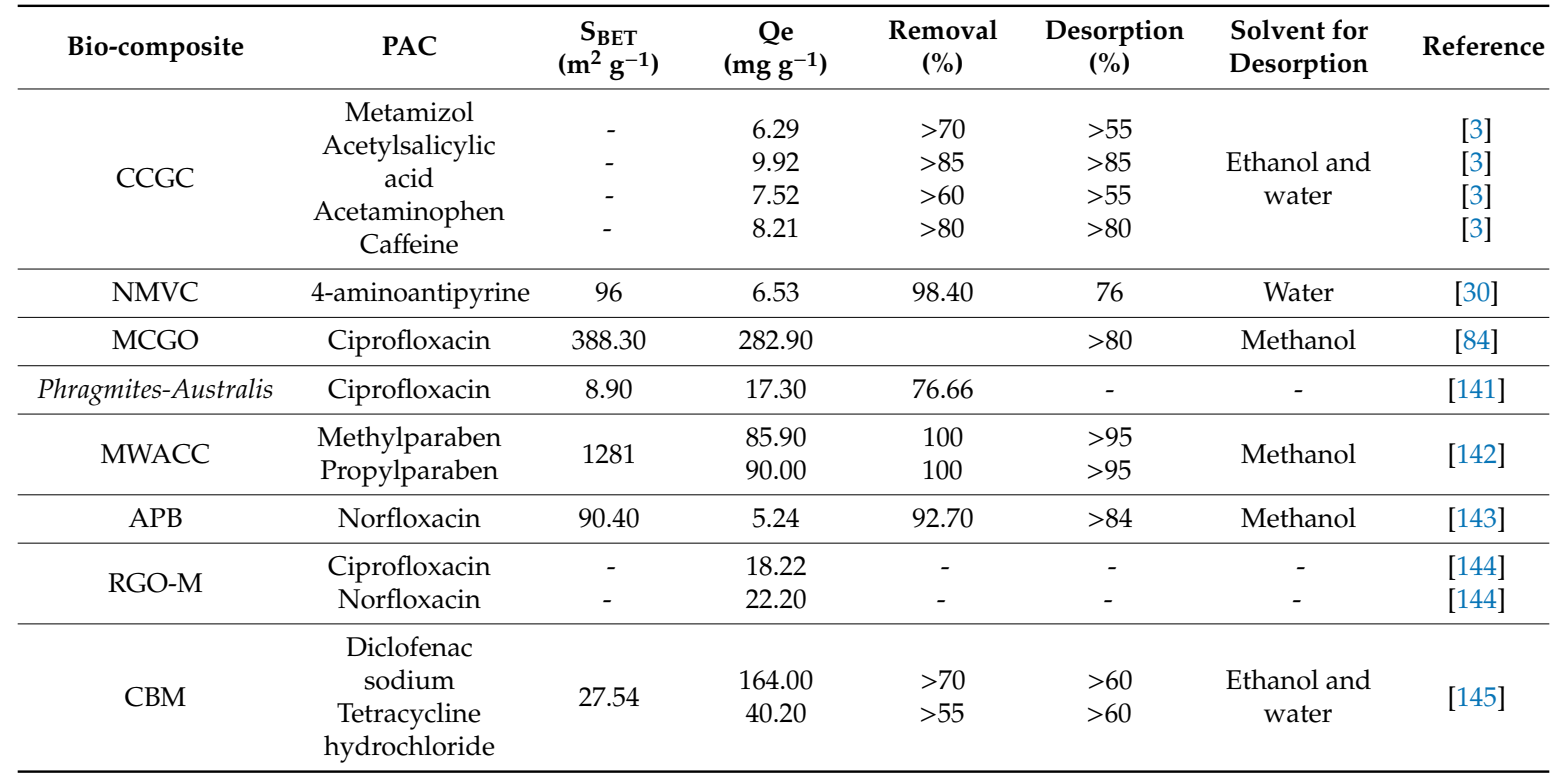

CCGC $=$ Chitosan/waste coffee-grounds composite, MWACC $=$ Magnetic waste tyre activated carbon-chitosan, APB = Clay-biochar composite with potato stem and natural attapulgite, $-=$ Not determined, NMVC $=$ Nanocellulose modified vermiculite clay, $\mathrm{MCGO}=$ Magnetic chitosan grafted graphene oxide nanocomposite, $\mathrm{RGO}-\mathrm{M}=$ Graphene oxide/magnetite composites, CBM = Chitosan-based magnetic composite, Qe = Adsorption capacity, $\mathrm{S}_{\mathrm{BET}}=$ Surface area.
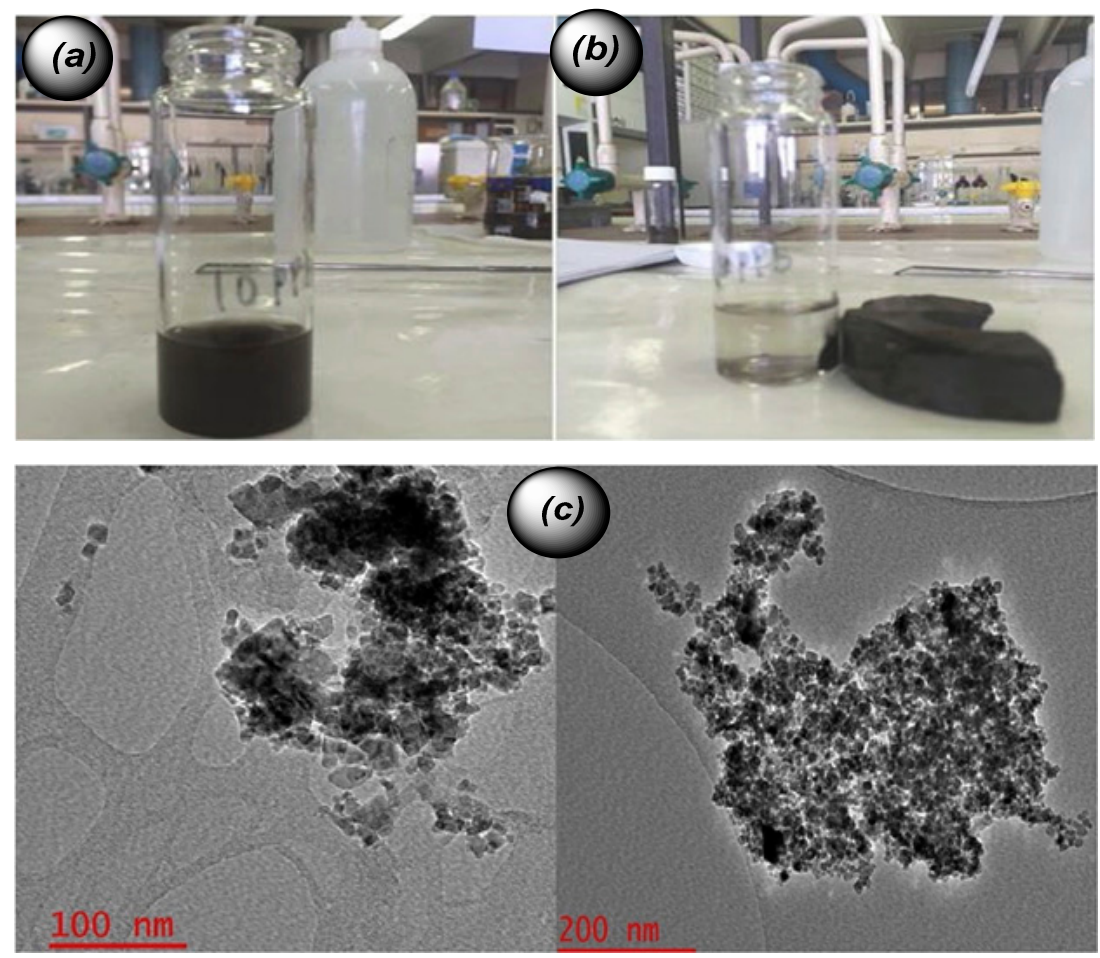

Figure 6. (a) Magnetic adsorbent dispersed in sample solution during the adsorption process, (b) Separation of sorbent using external magnet and (c) TEM of magnetic waste tyre coated activated carbon-chitosan under different magnifications [142]. 
Clays are hydrous aluminosilicates, which can be categorized mainly into montmorillonite, smectite, kaolinite, ilite, and chlorite. Among these categories, kaolinite, montmorillonite and ilite are mostly used, due to their physicochemical, structural and mechanical properties. The price is low as the cost of clay ranges between $\$ 0.005-0.46$ per $\mathrm{kg}[146,147]$. It contains exchangeable cations and anions such as $\mathrm{Ca}^{2+}, \mathrm{Mg}^{2+}, \mathrm{H}^{+}, \mathrm{K}^{+}, \mathrm{Na}^{+}, \mathrm{NH}_{4}{ }^{+}, \mathrm{Cl}^{-}, \mathrm{PO}_{4}{ }^{3-}$ and $\mathrm{NO}^{3-}$, which are easily exchanged with other ions without altering the clay structure [147]. Report from the previous study has shown that faces and edges of clay particles can adsorb charged (cations and anions) and neutral pollutants in water [147]. These properties qualify it as a material that can be combined with biopolymer to produce bio-composite. Clay-biochar composites have been produced for the enhancement of sorption capacity of biochar for certain contaminants [148]. Even though several methods have been used for the production of clay-biochar composites, the most frequently used method is pyrolysis [148,149]. Clay-biochar composite prepared by potato stem and natural attapulgite has shown higher sorption capacity for norfloxacin in the $\mathrm{pH}$ range of 2.0-11.0 [143]. Major sorption mechanisms involved were electrostatic attraction, hydrogen bonding, hydrophobic interaction, and $\pi-\pi$ interactions [150]. The sorption capacity was demonstrated in double distilled tap and river water, and the composite exhibited a removal of $84.14,82.17$ and $87.37 \%$, respectively. The regeneration of the bio-composite with methanol was stable up to the 5th cycle with a capacity greater than $84 \%$. This capacity relates well with values reported for the regeneration of magnetic waste tyre activated carbon-chitosan bio-composite [141], which presents bio-composites as promising materials for wastewater treatment.

Waste coffee-grounds, a poorly explored source of bio-compounds, were combined with chitosan and poly (vinyl alcohol) in order to obtain composite [3]. The composite exhibited a noticeable enhancement for the sorption of metamizol $\left(6.29 \mathrm{mg} \mathrm{g}^{-1}\right)$, acetylsalicylic acid $\left(9.92 \mathrm{mg} \mathrm{g}^{-1}\right)$, acetaminophen $\left(7.52 \mathrm{mg} \mathrm{g}^{-1}\right)$ and caffeine $\left(8.21 \mathrm{mg} \mathrm{g}^{-1}\right)$. The highest removal efficiency was registered at $\mathrm{pH} 6$, which obeyed the pseudo-second-order model and Freundlich isotherm. The composite is cost-effective with remarkable reusability of at least five consecutive biosorption/desorption cycles. Surfactant modified cellulose-montmorillonite composite has also been prepared as a biosorbent [151]. Aluminum-pillared kaolin sodium alginate beads (CA-Al-KABs) were prepared by gelling and solidification processes, which were used for the removal of ciprofloxacin in solution [32]. Sorption of ciprofloxacin was found to be $\mathrm{pH}$-dependent, pseudo-first-order kinetics model controlled and obeyed the Langmuir isotherm model with an adsorption capacity of $68.36 \mathrm{mg} \mathrm{g}^{-1}$. The mechanism for the sorption of ciprofloxacin is electrostatic attraction, as described in Figure 7a. Starch modified smectite clay composite has also been prepared and used for the removal of PACs from wastewater treatment plant effluent [152]. It is evident that most regeneration processes made use of polar solvents or a mixture of organic solvent with water as a means of an aqueous system for the regeneration of bio-composite. Alcohol is the most commonly used organic solvent, which might be due to the polar solubility of most of the PACs.

Graphene is a one-atom-thick, two-dimensional layer of $\mathrm{sp}^{2}$-hybridized carbon [153]. Its physicochemical, thermal, mechanical and electrical properties are extraordinary, which makes it suitable for different applications. The surface area is large, and its large delocalized $\pi$-electron system promotes interaction with other molecules [154,155]. This interaction is a pointer for its use as a material in the removal of PACs in the water system. It can hold oxygen-containing functional groups in its molecule to form reduced graphene (rGO) or graphene oxide (GO). This is an indication that it can be modified by grafting other functional groups onto it or by combination with other materials such as biopolymers. Its exceptional properties such as large surface area, short intra-particle diffusion path-length, high sorption site, low-temperature modification and ease of regeneration present graphene as an excellent material for composite preparation. When such composites are prepared in combination with a biopolymer, they are classified as a new class of fascinating bio-composite. One disadvantage that limits the use of graphene is the possibility of aggregation. However, this challenge is overcome by intercalating particles within the layers of graphene [144]. rGO/magnetite was prepared by Tang et al. [156] and used for the removal of norfloxacin and ciprofloxacin. The process 
was spontaneous and exothermic with sorption capacity of 22.20 and $18.22 \mathrm{mg} \mathrm{g}^{-1}$ for norfloxacin and ciprofloxacin, respectively. The process obeyed Temkin isotherm, Langmuir isotherm and pseudo-second-order kinetic models. It is $\mathrm{pH}$-dependent, and the removal mechanism consisted of electrostatic repulsions and $\pi-\pi$ interactions. GO may be incorporated into polymer membrane to boost performance in water treatment. A few reports cover the incorporation of GO into particular; poly ( $N$-vinylcarbazole), polyamide; and polysulfone membranes [157]. Inclusion of GO and activated carbon in polymer ultrafiltration membrane has shown improvement in hydrophilicity, electrostatic repulsion and pore size, which remarkably enhance removal of PACs in water [158]. Li et al. [159] reported the degradation of amoxicillin using magnetic $\mathrm{TiO}_{2}-\mathrm{GO}-\mathrm{Fe}_{3} \mathrm{O}_{4}$ composite with a submerged magnetic separation membrane photocatalytic reactor. $\mathrm{TiO}_{2}-\mathrm{GO}-\mathrm{Fe}_{3} \mathrm{O}_{4}$ was prepared with high Photo-Fenton catalytic performance and capability of magnetic recovery. $\mathrm{Fe}_{3} \mathrm{O}_{4}$ not only enhanced Fenton degradation of amoxicillin but also contributed to the magnetism of the photocatalyst for magnetic separation from treated water. The study revealed an excellent degradation of amoxicillin in a photodegradation process that is described in Figure $7 \mathrm{~b}$. It is also obvious in Table 6 that bio-composite prepared with the inclusion of GO exhibited high surface area and high adsorption capacity when compared with other bio-composites which did not include GO. The high surface area exhibited by the bio-composite might be due to the high surface area of GO, although the authors reported that the initial high surface area of GO reduced after inclusion for the preparation of bio-composite, which may be due to the aggregation resulting from the interaction with biomass. Most bio-composites remained steady in their regeneration and adsorption capacity up to 5-8 cycles, which makes them outstanding. Unfortunately, there is limited information on desorption studies or regeneration of plant-based biosorbents, as shown in Table 4, unlike the case for bio-composite. Apart from this, the introduction of magnetic properties into some of the reported bio-composites [142] as described in Figure 6 makes them stand out. The magnetic properties demonstrated by such bio-composites makes it easy to separate the biosorbent from the treated water system, unlike other biosorbents which required filtration and other steps, which adds extra cost to the actual treatment cost.

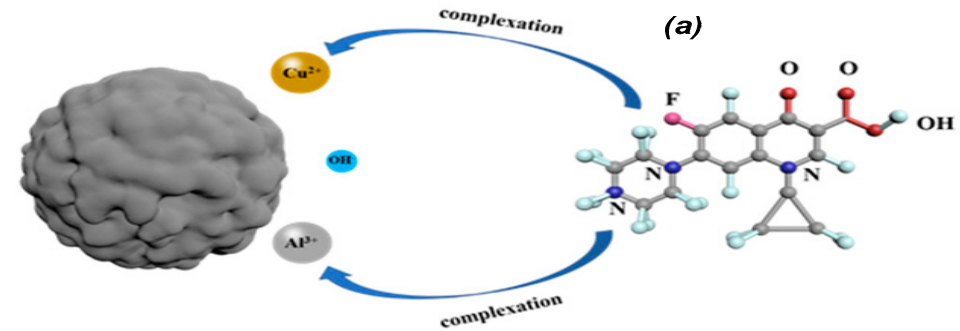

(b)

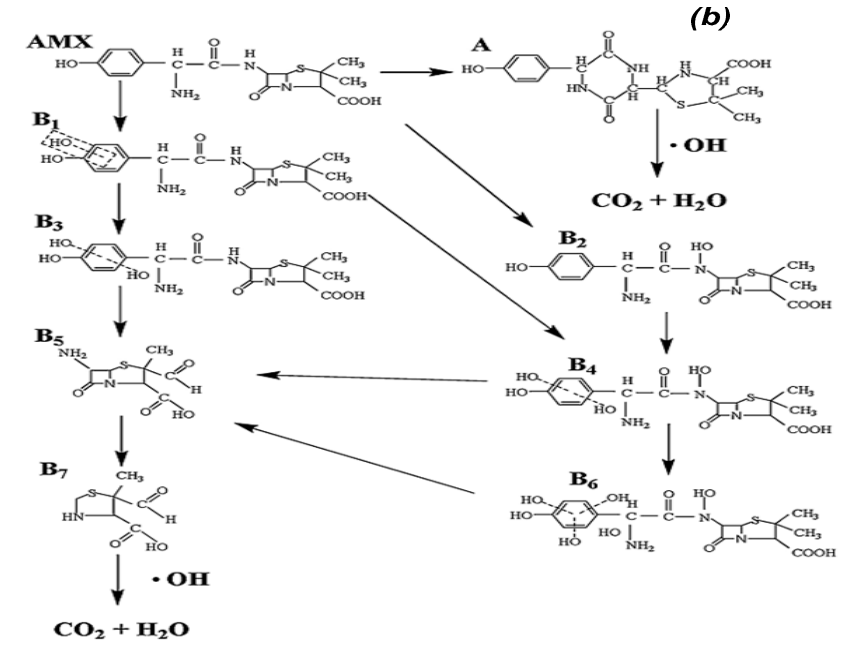

Figure 7. (a) The mechanism of ciprofloxacin loaded on CA-Al-KABs [32], (b) Mineralization pathways of amoxicillin (AMX) in water by submerged magnetic separation membrane photocatalytic reactor [159]. 


\subsection{Desorption and Regeneration}

The reusability of biosorbent is essential. This involves the removal of adsorbate from the surface of the biosorbent after use and the biosorbent should return to almost its original form in morphology and effectiveness. The number of cycles in which biosorbents can be reused goes a long way in determining their economic value and viability. One of the key achievements of biosorbents is their recovery after usage. Developing a suitable system for desorption is very important. It is not sufficient for a biosorbent to exhibit high performance alone, but reusability is equally essential. Therefore, desorption and regeneration are the fundamental processes to check when selecting biosorbents. Many materials have been developed in the past as biosorbents for removal of PACs from the water system. However, some of them are not easily regenerated, which makes their continuous use questionable, as they will have to be discarded after completing a circle or two. Discarding such material may also lead to an environmental pollution problem. It is very important that, after the sorption process, spent biosorbents are separated from the medium, regenerated and recycled. Several methods have been developed for the desorption process. However, the use of eluents is still the most commonly used process. Ability to select the most suitable eluent is very vital, a process, which depends on the type of biosorbent, adsorbate and mechanism of biosorption. An appropriate eluent should not damage or change the structure of the biosorbent, should be environmentally friendly, cheap, have high affinity for the adsorbate, not alter the adsorbate or biosorbent and should easily separate from the adsorbate.

Previously used eluents include mineral acids [30], organic acids and solvents [160], and complexing agents [161]. Desorption may be performed in batch or column, although the desorption process is easier in a packed column arrangement. When the sorption process is in a column, it is better to perform the desorption in the column as well. For example, once the sorption process becomes saturated, it is better to switch to desorption by allowing the eluent to flow through the column. It is important to carefully monitor the process so as not to overstretch the biosorbent; however, this also depends on the strength of the biosorbent. The potential of a desorption process relies on the removal mechanisms and the mechanical stability of the biosorbent. Since most biosorbents exhibit ion-exchange or ionic interaction towards positively charged PACs, use of mild to strong acidic systems should sufficiently achieve the desorption. This becomes beneficial since acidic solutions are common waste, generated in most industries. Therefore, acidic solutions generated during industrial processes can find an application by serving as a means of regenerating spent biosorbents. Chakraborty et al. [162] reported the desorption of ibuprofen from bidirectional activated biochar from sugarcane bagasse. The desorption was carried out using $0.1 \mathrm{~N}$ methanol under continuous agitation at $130 \mathrm{rpm}$ for $24 \mathrm{~h}$ at $25{ }^{\circ} \mathrm{C}$. It was efficient even after 4 cycles up to values above $65 \%$. Desorption of diclofenac sodium and tetracycline hydrochloride from chitosan-based magnetic composite was achieved using ethanol and water (volume ratio of 1:1) with $1 \mathrm{wt} \%$ of $\mathrm{NaOH}$ [145]. For effective desorption, the alkaline condition was maintained since $\mathrm{Fe}_{3} \mathrm{O}_{4}$ is unstable at very low $\mathrm{pH}$. Furthermore, the solution of ethanol-water was used in order to dissolve diclofenac sodium and tetracycline hydrochloride. The process attained a regeneration efficiency of five cycles. Desorption and regeneration of biosorbent are carefully considered when selecting biosorbent for water treatment. Care should be taken to ensure that the integrity of the biosorbent is intact after desorption and regeneration. It has become apparent that selecting the most suitable system for desorption is a challenging task, which requires a detailed understanding of the biosorbent as well as the PACs.

\section{Cost Evaluation}

Estimating the cost of biosorption and biosorbent is not an easy task, and it is not often reported. Process treatment, transportation, energy consumption, maintenance, process optimization, regeneration, disposal and desorption are factors considered when making an estimate. It depends on the nature of water or wastewater to be treated, as well as volume. However, capital expenditure and running cost will depend on the type and size of the treatment plant. It is better to make use of waste as feedstock for biosorbent production to minimize process cost. Wastes generated from farm 
produce, domestic and industrial wastes such as bacterial waste from fermentation industries, fungal wastes from food processing industries and sludge from other processing industries are applicable in biosorbent production. Waste disposal is a major problem, therefore making use of these wastes solves the environmental problem and at the same time helps reduce the cost of producing biosorbents for water treatment. One factor that increases production cost is pretreatment given to feedstock. Some of these materials require some pretreatments before processing, and the extra pretreatment may increase production cost. However, it is important to consider an effective but cheap and affordable treatment. It is vital to ensure that the treatment facility is close to the source of waste to minimize cost. Disposal cost should be factored into the cost of biosorption because once the biosorbent is completely utilized in a repeated cycle, it has to be replaced, although the spent biosorbent might find application in other fields like in the production of particleboard, cement, biogas, etc.

Cost evaluation depends on several factors, which makes it difficult to generalize. Therefore, the cost may vary from one biosorbent to the other depending on composition. This will also include whether it is sourced from waste or neat feedstock. Biosorption cost will also depend on the capacity and behavior of the biosorbent used. For example, if the removal process is fast and completed within a short time, less energy is consumed, unlike a biosorbent with slow uptake and long sorption time. The more the energy consumption, the higher the cost of production. The biosorption process is economically feasible compared to other methods such as reverse osmosis, electrodialysis, advance oxidation and electrothermal methods, which cost about US \$450 per million liters whereas, depending on the type of biosorbent, the cost of water treatment per million liters is estimated as US \$10-US \$200 [163]. Use of chemicals is reduced, and when microorganisms are used, they can mineralize and degrade the PACs to forms that are readily adsorbed or wholly converted to $\mathrm{CO}_{2}$ and $\mathrm{H}_{2} \mathrm{O}$. Different costs have been reported in the literature, for example, bagasse fly ash costs US $\$ 0.02$ per $\mathrm{kg}$ [164], biochar costs US \$2.65 per kg [165], chitosan-based biosorbent costs US \$8-10 per kg [166] and kaolinite clay costs $\$ 0.005-0.46$ per $\mathrm{kg}$. The price may change depending on several economic factors.

\section{Future Perspectives for Biosorption}

With the current challenge of how to get rid of PACs in the environment, the government needs to develop a policy that will regulate the use of pharmaceutical products. Most countries do not have functional regulations to monitor and control the emergence of PACs in water. Moreover, current emerging PACs in water were not envisaged to occur in the water system; therefore, most of the currently used techniques for water treatment were not developed to cater for them. There is a need to develop efficient technologies that will help remove PACs entirely. However, biosorption has this advantage over other known methods. Nonetheless, most reported works on biosorption were laboratory-based and not on a large scale, which should be an area of focus. For biosorption to gain full operation, there is a need to conduct sufficient research on its use on a large scale for industrial purposes. To apply biosorption in real large-scale situation, there is a need to understand the response of biosorbent to operating parameters such as $\mathrm{pH}$, temperature, particle size and load on a large scale. Most published works were conducted on a small scale in the laboratory. Therefore, it is crucial to know whether the biosorbent will behave differently when subjected to these parameters on a large scale. This information is currently missing.

The fact that it is cheaper to produce biosorbents from waste is an indication that there would be a socio-economic viability for large tons of waste generated from bio-based industrial processes. The waste generated from agriculture is massive. Investing in the conversion of such waste to biosorbents will create jobs and a new avenue for developing biosorption to full industrial scale, although there is the possibility of competition between using agricultural wastes as biosorbent and as feedstock for biogas production. However, the biosorbent can still be used for biogas production after it is completely used up and has repeatedly completed its utilization cycle, which makes it a win-win situation. Even though biosorbents can find use in biogas production, it is crucial to develop good disposal practice for spent biosorbents. It may also be essential to develop other ways of making 
use of spent biosorbents. Microorganisms as biosorbents have shown exciting results in biosorption, biodegradation and bioaccumulation of PACs. Care must be taken when using living organisms not to create strains that would be resistant by mutating. It is important not to end up creating a new problem while trying to solve environmental challenges. The possibility of using microorganisms creates a new area of research of screening for novel strains of bacteria, fungi and algae that will be useful and efficient in wastewater purification. There is a need to pay more attention to understanding the mechanism by which these microorganisms remove PACs from water. The use of bio-composite has proven very useful for the removal of PACs in water, but the complexity and chemical reagent involved in its production increases cost. There is a need to research more on reducing production cost by reducing production steps and using simple and cheap chemical reagents for bio-composite preparation.

\section{Conclusions}

This review considers the role of chemically modified biosorbent in removing PACs in water. It identified a few biosorbents and their role. It revealed that modification of biosorbents is vital to improving their capacity. Most biosorbents are prepared from waste, which plays a crucial role in cost reduction. Bio-composites exhibited better prospect as biosorbents when compared with other biosorbents because they contain two or more distinct materials brought together to produce a new material with improved performance better than individual constituent materials. During the sorption process, $\mathrm{pH}$ plays an important role; most of the sorption processes were $\mathrm{pH}$-dependent. Use of living microorganisms showed that, apart from biosorption, the organisms are capable of bioaccumulating and biodegrading PACs. The majority of the sorption processes reported followed the pseudo-second-order model and can be described by the Langmuir isotherm model. Production of biosorbents was considered relatively cheap, efficient, and a promising means of removing PACs in the water system. Despite the numerous studies of biosorption, most of the works reported were laboratory-based (small-scale), and there is a need to conduct large-scale studies on the biosorption process for removing PACs in water.

Funding: This research received no external funding

Acknowledgments: Thanks for the support from the Department of Chemical Sciences, Redeemer's University.

Conflicts of Interest: There is no conflict of interest.

\section{References}

1. Tran, N.H.; Gin, K.Y.H. Occurrence and removal of pharmaceuticals, hormones, personal care products, and endocrine disrupters in a full-scale water reclamation plant. Sci. Total Environ. 2017, 599-600, 1503-1516.

2. Kostich, M.S.; Batt, A.L.; Lazorchak, J.M. Concentrations of prioritized pharmaceuticals in effluents from 50 large wastewater treatment plants in the US and implications for risk estimation. Environ. Pollut. 2014, 184, 354-359. [PubMed]

3. Lessa, E.F.; Nunes, M.L.; Fajardo, A.R. Chitosan/waste coffee-grounds composite: An efficient and eco-friendly adsorbent for removal of pharmaceutical contaminants from water. Carbohydr. Polym. 2018, 189, 257-266. [PubMed]

4. Larsson, D.G.J. Pollution from drug manufacturing: Review and perspectives. Philos. Trans. R. Soc. B Biol. Sci. 2014, 369, 1656. [CrossRef] [PubMed]

5. Yan, Z.; Lu, G.; Liu, J.; Jin, S. An integrated assessment of estrogenic contamination and feminization risk in fish in Taihu Lake, China. Ecotoxicol. Environ. Saf. 2012, 84, 334-340. [CrossRef] [PubMed]

6. Ikhwanuddin, M.; Bahar, H.; Ma, H.; Manan, H. Effect of estrogen hormone, 17 $\beta$-estradiol on feminization of banana shrimp, Penaeus merguiensis (de Man, 1888) postlarvae and the identification of the age of external sex differentiation. Aquac. Rep. 2019, 13, 100177. [CrossRef]

7. Porseryd, T.; Larsson, J.; Kellner, M.; Bollner, T.; Dinnetz, P.; Hallstrom, I.P. Altered non-reproductive behavior and feminization caused by developmental exposure to $17 \alpha$-ethinylestradiol persist to adulthood in three-spined stickleback (Gasterosteus aculeatus). Aquatic Toxicol. 2019, 207, 142-152. [CrossRef] 
8. Quesada, H.B.; Baptista, A.T.A.; Cusioli, L.F.; Seibert, D.; Bezerra, C.O.; Bergamasco, R. Surface water pollution by pharmaceuticals and an alternative of removal by low-cost adsorbents: A review. Chemosphere 2019, 222, 766-780. [CrossRef]

9. Hossain, A.; Nakamichi, S.; Habibullah-Al-Mamun, M.; Tani, K.; Masunaga, S.; Matsuda, H. Occurrence and ecological risk of pharmaceuticals in river surface water of Bangladesh. Environ. Res. 2018, 165, 258-266. [CrossRef]

10. Asghar, M.A.; Zhu, Q.; Sun, S.; Peng, Y.; Shuai, Q. Suspect screening and target quantification of human pharmaceutical residues in the surface water of Wuhan, China, using UHPLC-Q-Orbitrap HRMS. Sci. Total Environ. 2018, 635, 828-837. [CrossRef]

11. Bean, T.G.; Rattner, B.A.; Lazarus, R.S.; Day, D.D.; Burket, S.R.; Brooks, B.W.; Haddad, S.P.; Bowerman, W.W. Pharmaceuticals in water, fish and osprey nestlings in Delaware River and Bay. Environ. Pollut. 2018, 232, 533-545. [CrossRef] [PubMed]

12. Rivera-Jaimes, J.A.; Postigo, C.; Melgoza-Aleman, R.M.; Acena, J.; Barcelo, D.; Lopez de Alda, M. Study of pharmaceuticals in surface and wastewater from Cuernavaca, Morelos, Mexico: Occurrence and environmental risk assessment. Sci. Total Environ. 2018, 613-614, 1263-1274. [CrossRef] [PubMed]

13. Fick, J.; Söderström, H.; Lindberg, R.H.; Phan, C.; Tysklind, M.; Larsson, D.G.J. Contamination of surface, ground, and drinking water from pharmaceutical production. Environ. Toxicol. Chem. 2009, 28, 2522-2527. [CrossRef] [PubMed]

14. Azanu, D.; Styrishave, B.; Darko, G.; Weisser, J.J.; Abaidoo, R.C. Occurrence and risk assessment of antibiotics in water and lettuce in Ghana. Sci. Total Environ. 2018, 622-623, 293-305. [CrossRef] [PubMed]

15. Madikizela, L.M.; Tavengwa, N.T.; Chimuka, L. Status of pharmaceuticals in African water bodies: Occurrence, removal and analytical methods. J. Environ. Manag. 2017, 193, 211-220.

16. Lindim, C.; van Gils, J.; Georgieva, D.; Mekenyan, O.; Cousins, I.T. Evaluation of human pharmaceutical emissions and concentrations in Swedish river basins. Sci. Total Environ. 2016, 572, 508-519.

17. Carmona, E.; Andreu, V.; Pico, Y. Occurrence of acidic pharmaceuticals and personal care products in Turia River Basin: From waste to drinking water. Sci. Total Environ. 2014, 484, 53-63.

18. Burns, E.E.; Carter, L.J.; Kolpin, D.W.; Thomas-Oates, J.; Boxall, A.B.A. Temporal and spatial variation in pharmaceutical concentrations in an urban river system. Water Res. 2018, 137, 72-85. [CrossRef]

19. Praveena, S.M.; Shaifuddin, S.N.M.; Sukiman, S.; Nasir, F.A.M.; Hanafi, Z.; Kamarudin, N.; Ismail, T.H.T.; Aris, A.Z. Pharmaceuticals residues in selected tropical surface water bodies from Selangor (Malaysia): Occurrence and potential risk assessments. Sci. Total Environ. 2018, 642, 230-240.

20. Matongo, S.; Birungi, G.; Moodley, B.; Ndungu, P. Pharmaceutical residues in water and sediment of msunduzi river, KwaZulu-Natal, South Africa. Chemosphere 2015, 134, 133-140. [CrossRef]

21. Pereira, A.M.P.T.; Silva, L.J.G.; Laranjeiro, C.S.M.; Meisel, L.M.; Lino, C.M.; Pena, A. Human pharmaceuticals in Portuguese rivers: The impact of water scarcity in the environmental risk. Sci. Total Environ. 2017, 609, 1182-1191. [PubMed]

22. Caban, M.; Lis, E.; Kumirska, J.; Stepnowski, P. Determination of pharmaceutical residues in drinking water in Poland using a new SPE-GC-MS(SIM) method based on Speedisk extraction disks and DIMETRIS derivatization. Sci. Total Environ. 2015, 538, 402-411. [CrossRef] [PubMed]

23. Mutiyar, P.K.; Gupta, S.K.; Mittal, A.K. Fate of pharmaceutical active compounds (PhACs) from River Yamuna, India: An ecotoxicological risk assessment approach. Ecotoxicol. Environ. Saf. 2018, 150, 297-304. [CrossRef]

24. Silva, A.; Delerue-Matos, C.; Figueiredo, S.A.; Freitas, O.M. The use of algae and fungi for removal of pharmaceuticals by bioremediation and biosorption processes: A Review. Water 2019, 11, 1555.

25. Bottoni, P.; Caroli, S.; Caracciolo, A.B. Pharmaceuticals as priority water contaminants. Toxicol. Environ. Chem. 2010, 92, 549-565. [CrossRef]

26. Akhtar, J.; Amin, N.A.S.; Shahzad, K. A review on removal of pharmaceuticals from water by adsorption. Desalin. Water Treat. 2016, 57, 12842-12860. [CrossRef]

27. Hokkanen, S.; Bhatnagar, A.; Sillanpää, M. A review on modification methods to cellulose-based adsorbents to improve adsorption capacity. Water Res. 2016, 91, 156-173. [CrossRef]

28. Xu, Y.; Liu, T.; Zhang, Y.; Ge, F.; Steel, R.M.; Sun, L. Advances in technologies for pharmaceuticals and personal care products removal. J. Mater. Chem. A 2017, 5, 12001-12014. 
29. Silva, C.P.; Jaria, G.; Otero, M.; Esteves, V.I.; Calisto, V. Waste-based alternative adsorbents for the remediation of pharmaceutical contaminated waters: Has a step forward already been taken? Bioresour. Technol. 2018, 250, 888-901.

30. Adewuyi, A.; Oderinde, R.A. Chemically modified vermiculite clay: A means to removing emerging contaminant from polluted water system in developing nation. Polym. Bull. 2019, 76, 4967-4989.

31. Lach, J. Adsorption of chloramphenicol on commercial and modified activated carbons. Water 2019, $11,1141$. [CrossRef]

32. Hu, Y.; Pan, C.; Zheng, X.; Liu, S.; Hu, F.; Xu, L.; Xu, G.; Peng, X. Removal of ciprofloxacin with aluminum-pillared kaolin sodium alginate beads (CA-Al-KABs): Kinetics, isotherms, and BBD model. Water 2020, 12, 905. [CrossRef]

33. Rodriguez, A.Z.; Wang, H.; Hu, L.; Zhang, Y.; Xu, P. Treatment of produced water in the permian basin for hydraulic fracturing: Comparison of different coagulation processes and innovative filter media. Water 2020, 12, 770. [CrossRef]

34. Zhang, G.; Yang, Y.; Lu, Y.; Chen, Y.; Li, W.; Wang, S. Effect of heavy metal Ions on steroid estrogen removal and transport in SAT using DLLME as a detection method of steroid estrogen. Water 2020, 12, 589. [CrossRef]

35. Jiang, M.; Yang, W.; Zhang, Z.; Yang, Z.; Wang, Y. Adsorption of three pharmaceuticals on two magnetic ion-exchange resins. J. Environ. Sci. 2015, 31, 226-234.

36. Nghiem, L.D.; Schafer, A.I.; Elimelech, M. Removal of natural hormones by nanofiltration membranes: Measurement, modeling, and mechanisms. Environ. Sci. Technol. 2004, 15, 1888-1896. [CrossRef] [PubMed]

37. Rana, D.; Scheier, B.; Narbaitz, R.M.; Matsuura, T.; Tabe, S.; Jasim, S.Y.; Khulbe, K.C. Comparison of cellulose acetate (CA) membrane and novel CA membranes containing surface modifying macromolecules to remove pharmaceutical and personal care product micropollutants from drinking water. J. Membr. Sci. 2012, 409, 346-354.

38. Rajapaksha, A.U.; Premarathna, K.S.D.; Gunarathne, V.; Ahmed, A.; Vithanage, M. Sorptive removal of pharmaceutical and personal care products from water and wastewater. In Pharmaceuticals and Personal Care Products: Waste Management and Treatment Technology; Butterworth-Heinemann, Elsevier: Oxford, UK, 2019; pp. 213-238.

39. Feng, Y.; Wang, C.; Liu, J.; Zhang, Z. Electrochemical degradation of 17-alphaethinylestradiol (EE2) and estrogenic activity changes. J. Environ. Monit. 2010, 12, 404-408. [CrossRef]

40. Sires, I.; Brillas, E. Remediation of water pollution caused by pharmaceutical residues based on electrochemical separation and degradation technologies: A review. Environ. Int. 2012, 40, 212-229. [CrossRef]

41. Méndez-Arriaga, F.; Torres-Palma, R.; Pétrier, C.; Esplugas, S.; Gimenez, J.; Pulgarin, C. Ultrasonic treatment of water contaminated with ibuprofen. Water Res. 2008, 42, 4243-4248. [CrossRef]

42. Ciríaco, L.; Anjo, C.; Correia, J.; Pacheco, M.; Lopes, A. Electrochemical degradation of ibuprofen on Ti/Pt/PbO 2 and Si/BDD electrodes. Electrochim. Acta 2009, 54, 1464-1472. [CrossRef]

43. Madhavan, J.; Grieser, F.; Ashokkumar, M. Combined advanced oxidation processes for the synergistic degradation of ibuprofen in aqueous environments. J. Hazard. Mater. 2010, 178, 202-208. [CrossRef] [PubMed]

44. Salaeh, S.; Perisic, D.J.; Biosic, M.; Kusic, H.; Babic, S.; Stangar, U.L.; Dionysiou, D.D.; Bozic, A.L. Diclofenac removal by simulated solar assisted photocatalysis using $\mathrm{TiO}_{2}$-based zeolite catalyst; mechanisms, pathways and environmental aspects. Chem. Eng. J. 2016, 304, 289-302. [CrossRef]

45. Hasan, Z.; Jhung, S.H. Removal of hazardous organics from water using metalorganic frameworks (MOFs): Plausible mechanisms for selective adsorptions. J. Hazard. Mater. 2015, 283, 329-339. [CrossRef]

46. Fomina, M.; Gadd, G.M. Biosorption: Current perspectives on concept, definition and application. Bioresour. Technol. 2014, 160, 3-14. [CrossRef]

47. Worch, E. Adsorption Technology in Water Treatment; de Gruyter, W., Ed.; Deutscher Kunstverlag: Berlin, Germany, 2012; p. 332.

48. Rostamian, R.; Behnejad, H. A comprehensive adsorption study and modeling of antibiotics as a pharmaceutical waste by graphene oxide nanosheets. Ecotoxicol. Environ. Saf. 2018, 147, 117-123. [CrossRef]

49. Basu, S.; Balakrishnan, M. Polyamide thin film composite membranes containing ZIF-8 for the separation of pharmaceutical compounds from aqueous streams. Sep. Purif. Technol. 2017, 179, 118-125. [CrossRef] 
50. Qian, K.; Kumar, A.; Zhang, H.; Bellmer, D.; Huhnke, R. Recent advances in utilization of biochar. Renew. Sustain. Energy Rev. 2015, 42, 1055-1064. [CrossRef]

51. Šolic, M.; Maletic, S.; Isakovski, M.K.; Nikic, J.; Watson, M.; Kónya, Z.; Trickovic, J. Comparing the adsorption performance of multiwalled carbon nanotubes oxidized by varying degrees for removal of low levels of copper, nickel and chromium (VI) from aqueous solutions. Water 2020, 12, 723. [CrossRef]

52. Vijayaraghavan, K.; Yun, Y.S. Bacterial biosorbents and biosorption. Biotechnol. Adv. 2008, 26, $266-291$. [CrossRef]

53. Tadkaew, N.; Hai, F.I.; Mcdonald, J.A.; Khan, S.J.; Nghiem, L.D. Removal of trace organics by MBR treatment: The role of molecular properties. Water Res. 2011, 45, 2439-2451. [CrossRef] [PubMed]

54. Adewuyi, A.; Pereira, F.V. Underutilized Luffa cylindrica sponge: A local bio-adsorbent for the removal of $\mathrm{Pb}$ (II) pollutant from water system. Beni-Suef Uni. J. Basic Appl. Sci. 2017, 6, 118-126.

55. Ngah, W.S.W.; Hanafiah, M.A.K.M. Removal of heavy metal ions from wastewater by chemically modified plant wastes as adsorbents: A review. Bioresour. Technol. 2008, 99, 3935-3948.

56. Ali, M.E.M.; Abd El-Aty, A.M.; Badawy, M.I.; Ali, R.K. Removal of pharmaceutical pollutants from synthetic wastewater using chemically modified biomass of green alga Scenedesmus obliquus. Ecotoxicol. Environ. Saf. 2018, 151, 144-152. [PubMed]

57. Onal, Y.; Akmil-Basar, C.; Sarıc1-Ozdemir, C. Elucidation of the naproxen sodium adsorption onto activated carbon prepared from waste apricot: Kinetic, equilibrium and thermodynamic characterization. J. Hazard. Mater. 2007, 148, 727-734. [PubMed]

58. Cazetta, A.L.; Martins, A.C.; Pezoti, O.; Bedin, K.C.; Beltrame, K.K.; Asefa, T.; Almeida, V.C. Synthesis and application of N-S-doped mesoporous carbon obtained from nanocasting method using bone char as heteroatom precursor and template. Chem. Eng. J. 2016, 300, 54-63.

59. Rosli, N.; Ngadi, N.; Azman, M.A. Synthesis of modified spent tea for aspirin adsorption in aqueous solution. Inter. J. Rec. Technol. Eng. 2019, 8, 531-534.

60. Mestre, A.S.; Pires, J.; Nogueira, J.M.F.; Carvalho, A.P. Activated carbons for the adsorption of ibuprofen. Carbon 2007, 45, 1979-1988. [CrossRef]

61. Baccar, R.; Sarrà, M.; Bouzid, J.; Feki, M.; Blánquez, P. Removal of pharmaceutical compounds by activated carbon prepared from agricultural by-product. Chem. Eng. J. 2012, 211-212, 310-317. [CrossRef]

62. Mondal, S.; Aikat, K.; Halder, G. Biosorptive uptake of ibuprofen by chemically modified Parthenium hysterophorus derived biochar: Equilibrium, kinetics, thermodynamics and modeling. Ecol. Eng. 2016, 92, 158-172. [CrossRef]

63. Essandoh, M.; Kunwar, B.; Pittman, C.U.; Mohan, D.; Mlsna, T. Sorptive removal of salicylic acid and ibuprofen from aqueous solutions using pine wood fast pyrolysis biochar. Chem. Eng. J. 2015, 265, $219-227$. [CrossRef]

64. Mestre, A.S.; Bexiga, A.S.; Proença, M.; Andrade, M.; Pinto, M.L.; Matos, I.; Fonseca, I.M.; Carvalho, A.P. Activated carbons from sisal waste by chemical activation with $\mathrm{K}_{2} \mathrm{CO}_{3}$ : Kinetics of paracetamol and ibuprofen removal from aqueous solution. Bioresour. Technol. 2011, 102, 8253-8260. [CrossRef] [PubMed]

65. Ribeiro, A.V.F.N.; Belisário, M.; Galazzi, R.M.; Balthazar, D.C.; Pereira, M.G.; Ribeiro, J.N. Evaluation of two bioadsorbents for removing paracetamol from aqueous media. Electron. J. Biotechnol. 2011, 14, 1-10.

66. Ornek, A.; Ozacar, M.; Sengil, I.A. Adsorption of $\mathrm{Pb}(\mathrm{II})$ onto formaldehyde or sulphuric acid treated acorn waste: Equilibrium and kinetic studies. Biochem. Eng. J. 2007, 37, 192-200. [CrossRef]

67. Saka, C.; Sahin, O.; Kucuk, M.M. Applications on agricultural and forest waste adsorbentsfor the removal of lead (II) from contaminated waters. Int. J. Environ. Sci. Technol. 2012, 9, 379-394. [CrossRef]

68. Ramachandran, V.; Pujari, N.; Matey, T.; Kulkarni, S. Enzymatic hydrolysis of cassava using wheat seedlings. Int. J. Sci. Eng. Technol. Res. 2014, 3, 1216-1219.

69. Kulkarni, S.J. Use of biotechnology for synthesis of various products from different feedstocks-a review. Int. J. Adv. Res. Bio-Technol. 2014, 2, 1-3.

70. Rajapaksha, A.U.; Vithanage, M.; Ahmad, M.; Seo, D.C.; Cho, J.S.; Lee, S.E.; Lee, S.S.; Ok, Y.S. Enhanced sulfamethazine removal by steam-activated invasive plant-derived biochar. J. Hazard. Mater. 2015, 290, 43-50.

71. Chen, Y.; Wang, F.; Duan, L.; Yang, H.; Gao, J. Tetracycline adsorption onto rice husk ash, an agricultural waste: Its kinetic and thermodynamic studies. J. Mol. Liq. 2016, 222, 487-494. [CrossRef] 
72. Bernardo, M.; Rodrigues, S.; Lapa, N.; Matos, I.; Lemos, F.; Batista, M.K.S.; Carvalho, A.P.; Fonseca, I. High efficacy on diclofenac removal by activated carbon produced from potato peel waste. Int. J. Environ. Sci. Technol. 2016, 13, 1989-2000. [CrossRef]

73. Pouretedal, H.R.; Sadegh, N. Effective removal of amoxicillin, cephalexin, tetracycline and penicillin G from aqueous solutions using activated carbon nanoparticles prepared from vine wood. J. Water Process Eng. 2014, 1, 64-73. [CrossRef]

74. Ahmed, M.B.; Zhou, J.L.; Ngo, H.H.; Guo, W.; Johir, M.A.H.; Sornalingam, K. Single and competitive sorption properties and mechanism of functionalized biochar for removing sulfonamide antibiotics from water. Chem. Eng. J. 2017, 311, 348-358.

75. Wang, H.; Chu, Y.; Fang, C.; Huang, F.; Song, Y.; Xue, X. Sorption of tetracycline on biochar derived from rice straw under different temperatures. PLoS ONE 2017, 12, e0182776.

76. Zhang, H.; Wang, Z.; Li, R.; Guo, J.; Li, Y.; Zhu, J.; Xie, X. TiO 2 supported on reed straw biochar as an adsorptive and photocatalytic composite for the efficient degradation of sulfamethoxazole in aqueous matrices. Chemosphere 2017, 185, 351-360. [CrossRef] [PubMed]

77. El-Shafey, E.S.I.; Al-Lawati, H.; Al-Sumri, A.S. Ciprofloxacin adsorption from aqueous solution onto chemically prepared carbon from date palm leaflets. J. Environ. Sci. 2012, 24, 1579-1586.

78. Balarak, D.; Mostafapour, F.K. Canola residual as a biosorbent for antibiotic metronidazole removal. Pharm. Chem. J. 2016, 3, 12-17.

79. N'diaye, A.D.; Bollahi, M.A.; Kankou, M.S.A. Sorption of paracetamol from aqueous solution using groundnut shell as a low cost sorbent. J. Mater. Environ. Sci. 2019, 10, 553-562.

80. Aziz, S.S.; Mushtaq, S.; Begum, N. Adsorption studies of acetic acid removal from waste water using seeds of Brassica nigra. Int. J. Eng. Res. Appl. 2017, 7, 1-3.

81. Silva, B.; Martins, M.; Rosca, M.; Rocha, V.; Lago, A.; Neves, I.C.; Tavares, T. Waste-based biosorbents as cost-effective alternatives to commercial adsorbents for the retention of fluoxetine from water. Sep. Purif. Technol. 2020, 235, 116-139.

82. Martins, A.C.; Pezoti, O.; Cazetta, A.L.; Bedin, K.C.; Yamazaki, D.A.S.; Bandoch, G.F.G.; Asefa, T.; Visentainer, J.V.; Almeida, V.C. Removal of tetracycline by NaOH-activated carbon produced from macadamia nut shells: Kinetic and equilibrium studies. Chem. Eng. J. 2015, 260, 291-299. [CrossRef]

83. Kumar, A.; Sharma, G.; Naushad, M.; Al-Muhtaseb, A.; Hira, I.; Ahamad, T.; Kumar, A.; Ghfar, A.A.; Stadler, F.J. Visible photodegradation of ibuprofen and 2,4-D in simulated waste water using sustainable metal free-hybrids based on carbon nitride and biochar. J. Environ. Manag. 2019, 231, 1164-1175. [CrossRef]

84. Wang, F.; Yang, B.; Wang, H.; Song, Q.; Tan, F.; Cao, Y. Removal of ciprofloxacin from aqueous solution by a magnetic chitosan grafted graphene oxide composite. J. Mol. Liq. 2016, 222, 188-194.

85. Paunovic, O.; Pap, S.; Maletic, S.; Taggart, M.A.; Boskovic, N.; Sekulic, M.T. Ionisable emerging pharmaceutical adsorption onto microwave functionalised biochar derived from novel lignocellulosic waste biomass. J. Colloid Interface Sci. 2019, 547, 350-360. [CrossRef]

86. Villaescusa, I.; Fiol, N.; Poch, J.; Bianchi, A.; Bazzicalupi, C. Mechanism of paracetamol removal by vegetable wastes: The contribution of $\pi-\pi$ interactions, hydrogen bonding and hydrophobic effect. Desalination 2011, 270, 135-142. [CrossRef]

87. Yusoff, N.A.; Ngadi, N.; Alias, H.; Jusoh, M. Chemically treated chicken bone waste as an efficient adsorbent for removal of acetaminophen. Chem. Eng. Trans. 2017, 56, 925-930.

88. Khazri, H.; Ghorbel-Abid, I.; Kalfat, R.; Trabelsi-Ayadi, M. Extraction of clarithromycin and atenolol by cuttlefish bone powder. Environ. Technol. 2018, 38, 2662-2668. [CrossRef]

89. Benjedim, S.; Romero-Cano, L.A.; Pérez-Cadenas, A.F.; Bautista-Toledo, M.I.; Lotfi, E.; Carrasco-Marín, F. Removal of emerging pollutants present in water using an E-coli biofilm supported onto activated carbons prepared from argan wastes: Adsorption studies in batch and fixed bed. Sci. Total Environ. 2020, 720, 137491. [CrossRef]

90. Adewuyi, A.; Göpfert, A.; Adewuyi, O.A.; Wolff, T. Adsorption of 2-chlorophenol onto the surface of underutilized seed of Adenopus breviflorus: A potential means of treating waste water. J. Environ. Chem. Eng. 2016, 4, 664-672. [CrossRef]

91. Kizilkaya, B.; Tekinay, A.A.; Dilgin, Y. Adsorption and removal of Cu (II) ions from aqueous solution using pretreated fish bones. Desalination 2010, 264, 37-47. 
92. Dahiya, S.; Tripathi, R.M.; Hegde, A.G. Biosorption of lead and copper from aqueous solutions by pre-treated crab and arca shell biomass. Bioresour. Technol. 2008, 99, 179-187. [CrossRef]

93. Ojedokun, A.T.; Bello, O.S. Sequestering heavy metals from wastewater using cow dung. Water Resour. Ind. 2016, 13, 7-13. [CrossRef]

94. Vasanthakumar, K.; Bhagavanalu, D.V.S. Adsorption of basic dye from its aqueous solution on to bio-organic waste. J. Ind. Pollut. Control 2003, 19, 20-28.

95. El Haddad, M.; Mamouni, R.; Slimani, R.; Saffaj, N.; Ridaoui, M.; ElAntri, S.; Lazar, S. Adsorptive removal of reactive yellow 84 dye from aqueous solutions onto animal bone meal. J. Mater. Environ. Sci. 2012, 3, 1019-1026.

96. Nworu, J.S.; Enemose, E.A.; Osideru, O.O.; Emmanuel, O.A. Efficiency of animal (Cow, Donkey, Chicken and Horse) bones, in removal of hexavalent chromium from aqueous solution as a low cost adsorbent. Am. J. Appl. Chem. 2019, 7, 1-9.

97. Banat, F.A.; Al-Asheh, S. The use of human hair waste as a phenol biosorbent. Adsorp. Sci. Technol. 2001, 19, 599-608. [CrossRef]

98. Volesky, B.; Schiewer, S. Biosorption of metals. In Encyclopedia of Bioprocess Technology; Flickinger, M., Drew, S.W., Eds.; Wiley: New York, NY, USA, 1999; pp. 433-453.

99. Aydin, S. Enhanced biodegradation of antibiotic combinations via the sequential treatment of the sludge resulting from pharmaceutical wastewater treatment using white-rot fungi Trametes versicolor and Bjerkandera adusta. Appl. Microbiol. Biotechnol. 2016, 100, 6491-6499. [CrossRef]

100. Doyle, R.J.; Matthews, T.H.; Streips, U.N. Chemical basis for selectivity of metal ions by the Bacillus subtilis cell wall. J. Bacteriol. 1980, 143, 471-480. [CrossRef]

101. Phoenix, V.R.; Martinez, R.E.; Konhauser, K.O.; Ferris, F.G. Characterization and implications of the cell surface reactivity of Calothrixsp. strain KC97. Appl. Environ. Microbiol. 2002, 68, 4827-4834. [CrossRef]

102. Kazy, S.K.; Das, S.K.; Sar, P. Lanthanum biosorption by a Pseudomonassp.: Equilibrium studies and chemical characterization. J. Ind. Microbiol. Biotechnol. 2006, 33, 773-783. [CrossRef]

103. Vannela, R.; Verma, S.K. $\mathrm{Cu}^{2+}$ removal and recovery by SpiSORB: Batch stirred and up-flow packed bed columnar reactor systems. Bioprocess Biosyst. Eng. 2006, 29, 7-17. [CrossRef]

104. Vijayaraghavan, K.; Han, M.H.; Choi, S.B.; Yun, Y.S. Biosorption of reactive black 5 by Corynebacterium glutamicum biomass immobilized in alginate and polysulfone matrices. Chemosphere 2007, 68, 1838-1845. [CrossRef]

105. Vijayaraghavan, K.; Yun, Y.S. Chemical modification and immobilization of Corynebacterium glutamicum for biosorption of reactive black 5 from aqueous solution. Ind. Eng. Chem. Res. 2007, 46, 608-617. [CrossRef]

106. Martins, M.; Sanches, S.; Pereira, I.A.C. Anaerobic biodegradation of pharmaceutical compounds: New insights into the pharmaceutical-degrading bacteria. J. Hazard. Mater. 2018, 357, 289-297.

107. Wang, L.; Qiang, Z.; Li, Y.; Ben, W. An insight into the removal of fluoroquinolones in activated sludge process: Sorption and biodegradation characteristics. J. Environ. Sci. 2017, 56, 263-271. [CrossRef]

108. Sun, H.; Wang, T.; Yang, Z.; Yu, C.; Wu, W. Simultaneous removal of nitrogen and pharmaceutical and personal care products from the effluent of waste water treatment plants using aerated solid-phase denitrification system. Bioresour. Technol. 2019, 287, 121389.

109. Rana, R.S.; Singh, P.; Kandari, V.; Singh, R.; Dobhal, R.; Gupta, S. A review on characterization and bioremediation of pharmaceutical industries' wastewater: An Indian perspective. Appl. Water Sci. 2017, 7, 1-12. [CrossRef]

110. Yu, J.; Tong, M.; Sun, X.; Li, B. A simple method to prepare poly (amic acid)-modified biomass for enhancement of lead and cadmium adsorption. Biochem. Eng. J. 2007, 33, 126-133. [CrossRef]

111. Göksungur, Y.; Üren, S.; Güvenc, U. Biosorption of cadmium and lead ion by ethanol treated waste baker's yeast biomass. Bioresour. Technol. 2005, 96, 103-109. [CrossRef]

112. Dhankhar, R.; Hooda, A. Fungal biosorption-An alternative to meet the challenges of heavy metal pollution in aqueous solutions. Environ. Technol. 2011, 32, 467-491. [CrossRef]

113. Ridvan, S.; Nalan, Y.; Adil, D. Biosorption of cadmium, lead, mercury and arsenic ions by fungus Penicillium purpurogenum. Sep. Sci. Technol. 2003, 39, 2039-2053.

114. Gadd, G.M. Accumulation and transformation of metals by microorganisms. In Biotechnology: A Multi-Volume Comprehensive Treatise, Vol. 10 Special Processes; Rehm, H.J., Reed, G., Puhler, A., Stadler, P., Eds.; Wiley: Weinheim, Germany, 2001; pp. 225-264. 
115. Becker, D.; Rodriguez-Mozaz, S.; Insa, S.; Schoevaart, R.; Barceloó, D.; de Cazes, M.; Belleville, M.P.; Sanchez-Marcano, J.; Misovic, A.; Oehlmann, J.; et al. Removal of endocrine disrupting chemicals in wastewater by enzymatic treatment with fungal laccases. Org. Process Res. Dev. 2017, 21, 480-491. [CrossRef]

116. Zhang, Y.; Geißen, S.U. Elimination of carbamazepine in a nonsterile fungal bioreactor. Bioresour. Technol. 2012, 112, 221-227. [CrossRef] [PubMed]

117. Rodriguez-Rodriguez, C.E.; García-Galán, M.J.; Blánquez, P.; Díaz-Cruz, M.S.; Barceló, D.; Caminal, G.; Vicent, T. Continuous degradation of a mixture of sulfonamides by Trametes versicolor and identification of metabolites from sulfapyridine and sulfathiazole. J. Hazard. Mater. 2012, 213-214, 347-354. [CrossRef] [PubMed]

118. Rodarte-Moralez, A.I.; Feijoo, G.; Moreira, M.T.; Lema, J.M. Operation of stirred tank reactors (STRs) and fixed-bed reactors (FBRs) with free and immobilized Phanerochaete chrysosporium for the continuous removal of pharmaceutical compounds. Biochem. Eng. J. 2012, 66, 38-45.

119. Lucas, D.; Castellet-Rovira, F.; Villagrasa, M.; Badia-Fabregat, M.; Barceló, D.; Vicent, T.; Caminal, G.; Sarràb, M.; Rodríguez-Mozaz, S. The role of sorption processes in the removal of pharmaceuticals by fungal treatment of wastewater. Sci. Total Environ. 2018, 610-611, 1147-1153.

120. González-Abradelo, D.; Pérez-Llano, Y.; Peidro-Guzmán, H.; Sánchez-Carbente, M.R.; Folch-Mallol, J.L.; Aranda, E.; Vaidyanathan, V.K.; Cabana, H.; Gunde-Cimerman, N.; Batista-García, R.A. First demonstration that ascomycetous halophilic fungi (Aspergillus sydowii and Aspergillus destruens) are useful in xenobiotic mycoremediation under high salinity conditions. Bioresour. Technol. 2019, 279, 287-296. [PubMed]

121. Vasiliadou, I.A.; Sanchez-Vazquez, R.; Molina, R.; Martínez, F.; Melero, J.A.; Bautista, L.F.; Iglesias, J.; Morales, G. Biological removal of pharmaceutical compounds using white-rotfungi with concomitant FAME production of the residual biomass. J. Environ. Manag. 2016, 180, 228-237. [CrossRef]

122. Badia-Fabregat, M.; Lucas, D.; Pereira, M.A.; Alves, M.A.; Pennanen, T.; Fritze, H.; Rodríguez-Mozaz, S.; Barceló, D.; Vicent, T.; Caminal, G. Continuous fungal treatment of non-sterile veterinary hospital effluent: Pharmaceuticals removal and microbial community assessment. Appl. Microbiol. Biotechnol. 2016, 100, 2401-2415. [CrossRef]

123. Becker, D.; Varela Della Giustina, S.; Rodriguez-Mozaz, S.; Schoevaart, R.; Barcelo, D.; de Cazes, M.; Belleville, M.P.; Sanchez-Marcano, J.; de Gunzburg, J.; Couillerot, O.; et al. Removal of antibiotics in wastewater by enzymatic treatment with fungal laccase-Degradation of compounds does not always eliminate toxicity. Bioresour. Technol. 2016, 219, 500-509.

124. Esterhuizen-Londt, M.; Schwartz, K.; Pflugmacher, S. Using aquatic fungi for pharmaceutical bioremediation: Uptake of acetaminophen by Mucor hiemalis does not result in an enzymatic oxidative stress response. Fungal Biol. 2016, 120, 1249-1257.

125. Palli, L.; Castellet-Rovira, F.; Péerez-Trujillo, M.; Caniani, D.; Sarrá-Adroguer, M.; Gori, R. Preliminary evaluation of Pleurotus ostreatus for the removal of selected pharmaceuticals from hospital wastewater. Biotechnol. Prog. 2017, 33, 1529-1537.

126. Pointing, S.B. Feasibility of bioremediation by white-rot fungi. Appl. Microbiol. Biotechnol. 2001, 57, $20-33$.

127. Wijffels, R.H.; Kruse, O.; Hellingwerf, K.J. Potential of industrial biotechnology with cyanobacteria and eukaryotic microalgae. Curr. Opin. Biotechnol. 2013, 24, 405-413.

128. Xiong, J.Q.; Govindwar, S.; Kurade, M.B.; Paeng, K.J.; Roh, H.S.; Khan, M.A.; Jeon, B.H. Toxicity of sulfamethazine and sulfamethoxazole and their removal by a green microalga, Scenedesmus obliquus. Chemosphere 2019, 218, 551-558. [CrossRef]

129. Xiong, J.Q.; Kurade, M.B.; Jeon, B.H. Can microalgae remove pharmaceutical contaminants from water? Trends Biotechnol. 2017, 36, 30-44. [CrossRef]

130. Matamoros, V.; Uggetti, E.; García, J.; Bayona, J.M. Assessment of the mechanisms involved in the removal of emerging contaminants by microalgae from wastewater: A laboratory scale study. J. Hazard. Mater. 2016, 301, 197-205. [CrossRef]

131. Peng, F.Q.; Ying, G.G.; Yang, B.; Liu, S.; Lai, H.J.; Liu, Y.S.; Chen, Z.F.; Zhou, G.J. Biotransformation of progesterone and norgestrel by two freshwater microalgae (Scenedesmus obliquus and Chlorella pyrenoidosa): Transformation kinetics and products identification. Chemosphere 2014, 95, 581-588. [CrossRef]

132. González-Pleiter, M.; Gonzalo, S.; Rodea-Palomares, I.; Leganés, F.; Rosal, R.; Boltes, K.; Marco, E.; Fernández-Piñas, F. Toxicity of five antibiotics and their mixtures towards photosynthetic aquatic organisms: Implications for environmental risk assessment. Water Res. 2013, 47, 2050-2064. [CrossRef] 
133. Xiong, J.Q.; Kurade, M.B.; Abou-Shanab, R.A.I.; Ji, M.K.; Choi, J.; Kim, J.O.; Jeon, B.H. Biodegradation of carbamazepine using freshwater microalgae Chlamydomonas mexicana and Scenedesmus obliquus and the determination of its metabolic fate. Bioresour. Technol. 2016, 205, 183-190. [CrossRef]

134. Ding, T.; Yang, M.; Zhang, J.; Lin, K.; Li, J.; Gan, J. Toxicity, degradation and metabolic fate of ibuprofen on freshwater diatom Naviculasp. J. Hazard. Mater. 2017, 330, 127-134.

135. Hom-Diaz, A.; Jaen-Gil, A.; Bello-Laserna, I.; Rodríguez-Mozaz, S.; Vincent, T.; Barceló, D.; Blánquez, P. Performance of a microalgal photobioreactor treating toilet wastewater: Pharmaceutically active compound removal and biomass harvesting. Sci. Total Environ. 2017, 592, 1-11. [CrossRef]

136. Escapa, C.; Coimbra, R.; Paniagua, S.; García, A.; Otero, M. Paracetamol and salicylic acid removal from contaminated water by microalgae. J. Environ. Manag. 2017, 203, 799. [CrossRef] [PubMed]

137. Amorim, C.L.; Moreira, I.S.; Maia, A.S.; Tiritan, M.E.; Castro, P.M.L. Biodegradation of ofloxacin, norfloxacin, and ciprofloxacin as single and mixed substrates by Labrys portucalensis F11. Appl. Microbiol. Biotechnol. 2014, 98, 3181-3190. [CrossRef] [PubMed]

138. Yang, S.; Hai, F.I.; Nghiem, L.D.; Nguyen, L.N.; Roddick, F.; Price, W.E. Removal of bisphenol a and diclofenac by a novel fungal membrane bioreactor operated under non-sterile conditions. Int. Biodeterior. Biodegrad. 2013, 85, 483-490. [CrossRef]

139. Zhang, L.; Xia, W.; Teng, B.; Liu, X.; Zhang, W. Zirconium cross-linked chitosan composite: Preparation, characterization and application in adsorption of Cr(VI). Chem. Eng. J. 2013, 229, 1-8. [CrossRef]

140. Rahim, M.; Haris, M.R.H.M. Application of biopolymer composites in arsenic removal from aqueous medium: A review. J. Radiat. Res. Appl. Sci. 2015, 8, 255-263. [CrossRef]

141. Karoui, S.; Ben, A.R.; Mougin, K.; Ghorbal, A.; Assadi, A.; Amrane, A. Synthesis of novel biocomposite powder for simultaneous removal of hazardous ciprofloxacin and methylene blue: Central composite design, kinetic and isotherm studies using Brouers-Sotolongo family models. J. Hazard. Mater. 2020, 387, 121675. [CrossRef]

142. Mashile, G.P.; Mpupa, A.; Nqombolo, A.; Dimpe, K.M.; Nomngongo, P.N. Recyclable magnetic waste tyre activated carbon-chitosan composite as an effective adsorbent rapid and simultaneous removal of methylparaben and propylparaben from aqueous solution and wastewater. J. Water Process Eng. 2020, 33, 101011. [CrossRef]

143. Li, Y.; Wang, Z.; Xie, X.; Zhu, J.; Li, R.; Qin, T. Removal of norfloxacin from aqueous solution by clay-biochar composite prepared from potato stem and natural attapulgite. Colloids Surf. A 2017, 514, 126-136. [CrossRef]

144. Wang, H.; Yuan, X.; Wu, Y.; Huang, H.; Peng, X.; Zeng, G.; Zhong, H.; Liang, J.; Ren, M.M. Graphene-based materials, fabrication, characterization and application for the decontamination of wastewater and waste gas and hydrogen storage/generation. Adv. Colloid Interface Sci. 2013, 195-196, 19-40. [CrossRef]

145. Zhang, S.; Dong, Y.; Yang, Z.; Yang, W.; Wu, J.; Dong, C. Adsorption of pharmaceuticals on chitosan-based magnetic composite particles with core-brush topology. Chem. Eng. J. 2016, 304, 325-334. [CrossRef]

146. Babel, S.; Kurniawan, T. A Low-cost adsorbents for heavy metals uptake from contaminated water: A review. J. Hazard. Mater. 2003, 97, 219-243. [CrossRef]

147. Srinivasan, R. Advances in application of natural clay and its composites in removal of biological, organic, and inorganic contaminants from drinking water. Adv. Mater. Sci. Eng. 2011, 2011, 1-17. [CrossRef]

148. Yao, Y.; Gao, B.; Fang, J.; Zhang, M.; Chen, H.; Zhou, Y.; Creamer, A.E.; Sun, Y.; Yang, L. Characterization and environmental applications of clay-biochar composites. Chem. Eng. J. 2014, 242, 136-143. [CrossRef]

149. Fosso-Kankeu, E.; Waanders, F.B.; Steyn, F.W. The preparation and characterization of clay-biochar composites for the removal of metal pollutants. In Proceedings of the Seventh International Conference on Latest Trends in Engineering \& Technology, Irene, Pretoria, South Africa, 26-27 November 2015.

150. Wang, W.; Zheng, B.; Deng, Z.; Feng, Z.; Fu, L. Kinetics and equilibriums for adsorption of poly(vinyl alcohol) from aqueous solution onto natural bentonite. Chem. Eng. J. 2013, 214, 343-354. [CrossRef]

151. Kumar, A.S.K.; Kalidhasan, S.; Rajesh, V.; Rajesh, N. Application of cellulose-clay composite biosorbent toward the effective adsorption and removal of chromium from industrial wastewater. Ind. Eng. Chem. Res. 2012, 51, 58-69. [CrossRef]

152. Amin, M.F.M.; Heijman, S.G.J.; Rietveld, L.C. Clay-starch combination for micropollutants removal from wastewater treatment plant effluent. Water Sci. Technol. 2016, 73, 1719-1727. [CrossRef] [PubMed]

153. Sophia, A.C.; Lima, E.C.; Allaudeen, N.; Rajan, S. Application of graphene based materials for adsorption of pharmaceutical traces from water and wastewater-a review. Desalin. Water Treat. 2016, 57, 27573-27586. 
154. Stoller, M.D.; Park, S.; Zhu, Y.; An, J.; Ruoff, R.S. Graphene-based ultracapacitors. Nano Lett. 2008, 8, 3498-3502. [CrossRef]

155. Georgakilas, V.; Otyepka, M.; Bourlinos, A.B.; Chan-dra, V.; Kim, N.; Kemp, K.C.; Hobza, P.; Zboril, R.; Kim, K.S. Functionalization of graphene: Covalent andnon-covalent approaches, derivatives and applications. Chem. Rev. 2012, 112, 6156-6214. [CrossRef]

156. Tang, Y.; Guo, H.; Xiao, L.; Yu, S.; Gao, N.; Wang, Y. Synthesis of reduced graphene oxide/magnetite composites and investigation of their adsorption performance of fluoroquinolone antibiotics. Colloids Surf. A Physicochem. Eng. Asp. 2013, 424, 74-80. [CrossRef]

157. Cao, B.; Ansari, A.; Yi, X.; Rodrigues, D.F.; Hu, Y. Gypsum scale formation on graphene oxide modified reverse osmosis membrane. J. Membr. Sci. 2018, 552, 132-143. [CrossRef]

158. Chu, K.H.; Fathizadeh, M.; Yu, M.; Flora, J.R.V.; Jang, A.; Jang, M.; Park, C.M.; Yoo, S.S.; Her, N.; Yoon, Y. Evaluation of removal mechanisms in a graphene oxide-coated ceramic ultrafiltration membrane for retention of natural organic matter, pharmaceuticals, and inorganic salts. ACS Appl. Mater. Interfaces 2017, 9, 40369-40377. [CrossRef] [PubMed]

159. Li, Q.; Kong, H.; Li, P.; Shao, J.; He, Y. Photo-Fenton degradation of amoxicillin via magnetic $\mathrm{TiO}_{2}$-graphene oxide- $\mathrm{Fe}_{3} \mathrm{O}_{4}$ composite with a submerged magnetic separation membrane photocatalytic reactor (SMSMPR). J. Hazard. Mater. 2019, 373, 437-446. [CrossRef] [PubMed]

160. Chen, L.; Li, X.; Tanner, E.E.L.; Compton, R.G. Catechol adsorption on graphene nanoplatelets, isotherm, flat to vertical phase transition and desorption kinetics. Chem. Sci. 2017, 8, 4771-4778. [CrossRef] [PubMed]

161. Oyetibo, G.O.; Ishola, S.T.; Ikeda-Ohtsubo, W.; Miyauchi, K.; Ilori, M.O.; Endo, G. Mercury bioremoval by Yarrowia strains isolated from sediments of mercury polluted estuarine water. Appl. Microbiol. Biotechnol. 2015, 99, 3651-3657. [CrossRef]

162. Chakraborty, P.; Show, S.; Banerjee, S.; Halder, G. Mechanistic insight into sorptive elimination of ibuprofen employing bidirectional activated biochar from sugarcane bagasse: Performance evaluation and cost estimation. J. Environ. Chem. Eng. 2018, 6, 5287-5300. [CrossRef]

163. de Andrade, J.1.R.; Oliveira, M.F.; da Silva, M.G.; Vieira, M.G. Adsorption of pharmaceuticals from water and wastewater using nonconventional low-cost materials: A Review. Ind. Eng. Chem. Res. 2018, 57, 3103-3127. [CrossRef]

164. Gupta, V.K.; Ali, I. Removal of lead and chromium from wastewater using bagasse fly ash a sugar industry waste. J. Colloid Interface Sci. 2004, 271, 321-328. [CrossRef]

165. Ahmed, M.B.; Zhou, J.L.; Ngo, H.H.; Guo, W. Insight into biochar properties and its cost analysis. Biomass Bioenergy 2016, 84, 76-86. [CrossRef]

166. Gandhi, M.R.; Meenakshi, S. Recent advancement in heavy metal removal onto silica-based adsorbents and chitosan composites-A review. In A Book on Ion Exchange, Adsorption and Solvent Extraction; Naushad, M., Al-Othman, Z.A., Eds.; Nova Science Publishers, Inc.: New York, NY, USA, 2013; pp. 201-230. 